\title{
15. LATE CRETACEOUS TO PLEISTOCENE SILICOFLAGELLATES FROM THE SOUTHERN SOUTHWEST PACIFIC, DSDP, LEG 29
}

\author{
Katharina Perch-Nielsen, Institute of Historical Geology and Palaeontology, Copenhagen K, Denmark ${ }^{1}$
}

\begin{abstract}
Rich and often well preserved silicoflagellate assemblages of Late Cretaceous and late Eocene to Pleistocene ages were studied from 6 of the 10 sites drilled on DSDP Leg 29. Based on the ratio of Dictyocha to Distephanus, rough estimates of paleotemperatures are given for the Neogene at Site 278, and for the late Eocene of Sites $277,280,281$, and 283. A local silicoflagellate zonal scheme is proposed and correlated to other zonal schemes. Short systematical notes are given on all species.
\end{abstract}

\section{INTRODUCTION}

Silicoflagellates, one-celled, flagellated siliceous algae of microscopic size, were studied from 6 of the 10 sites drilled in the southern Southwest Pacific Ocean during DSDP Leg 29. The locations of the sites investigated in this study are shown in Figure 1. The silicoflagellates present in the cores and their stratigraphic distribution is given in Table 1.

Late Cretaceous assemblages were found only at Site 275. Late Eocene silicoflagellates occur at four sites, Oligocene at three, Miocene and Pleistocene at two, and Pliocene at one. Thus, a silicoflagellate sequence from the late Eocene to the Pleistocene can be composed from the data available from this leg. Local silicoflagellate zones can be established (Table 2) and are compared to the zones proposed by other workers in other areas in Table 3.

The silicoflagellates were counted on smear slides prepared from the decalcified samples where necessary. For a few samples, slides were prepared from the greater than $53 \mu$ or $63 \mu$ fractions for completion of the species list only. Where reasonable, 100 or more specimens were counted. The counts are tabulated in Tables 4 to 9 . The light microscope (LM) was used for the counting, while some selected samples were studied with the Scanning Electron Microscope (SEM). This was used for better illustration of some species. Canada balsam was used as a mounting medium for the LM slides.

\section{PALEOENVIRONMENT}

\section{Temperature}

It has been shown by Gemeinhardt (1934) that the distribution of the living silicoflagellates is controlled to some extent by temperature. Mandra (1969b) presented a curve of the relationship between the sea-temperature and the ratio of Dictyocha to Distephanus, Dictyocha

'Present address: Department of Geology, Swiss Federal Institute of Technology, Zürich, Switzerland.

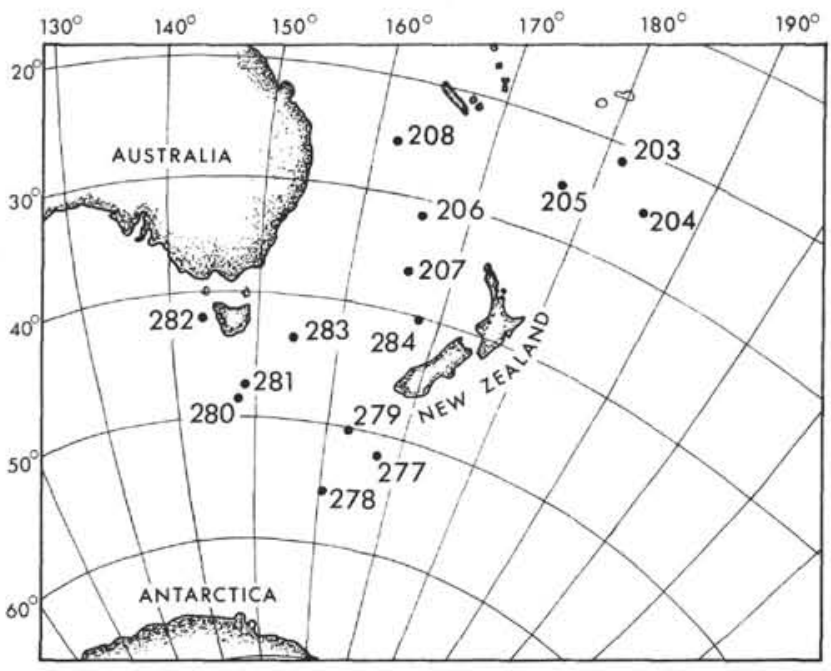

Figure 1. Sites drilled on DSDP Leg 29, and some sites of DSDP Leg 21.

favoring high and Distephanus favoring low temperatures. Bukry and Foster (1973) successfully used this curve for middle Miocene to Pleistocene cores from the equatorial eastern Pacific Ocean (Panama Basin).

Using the curve of Mandra (1969b), paleotemperatures were estimated for the Neogene sequence of Sites 278 and 281. Distephanus, mainly D. speculum dominates, usually in high numbers, over the forms of Dictyocha, indicating temperatures of around or below $5^{\circ} \mathrm{C}$. Only in one late Miocene sample (278-10-1, 110 $\mathrm{cm}$ ) does Dictyocha exceed Distephanus in a manner to suggest temperatures around $25^{\circ} \mathrm{C}$. This is a surprisingly high, and somewhat suspicious temperature for a site located at $56^{\circ} \mathrm{S}$. In the middle Miocene of the same hole, another sample indicates $10-15^{\circ} \mathrm{C}$ for that time. In samples from between late and middle Miocene Distephanus and Dictyocha are too rare to allow any conclusions. In samples taken from the early middle Miocene and lower (with the exception of 278-24, CC), 
TABLE 1

"Adopted Age" Assignments of the Core of Leg 29

Including Silicoflagellates and Silicoflagellate Zones

\begin{tabular}{|c|c|c|c|c|c|c|c|}
\hline \multirow{2}{*}{$\begin{array}{c}\text { Silicoflagellate } \\
\text { Zones and Subzones }\end{array}$} & \multicolumn{6}{|c|}{ Sites } & \multirow[b]{2}{*}{ Adopted Age } \\
\hline & 275 & 277 & 278 & 280 & 281 & 283 & \\
\hline Dictyocha aculeata & & & $\begin{array}{l}1,1 \mathrm{~A} \\
2 \mathrm{~A}\end{array}$ & & 1 & & Pleistocene \\
\hline Distephanus octogonus & & & $2-7$ & & & & \multirow{2}{*}{ Pliocene } \\
\hline Paradictyocha & & & 8 & & & & \\
\hline dumitricae & & & $14^{\frac{9}{-}}$ & & $6-8 ?$ & & \multirow{4}{*}{ Miocene } \\
\hline Distephanus crux & & & $\underline{21}$ & & & & \\
\hline Naviculopsis biapiculata & & & $22-26$ & & & & \\
\hline Naviculopsis robusta & & & $27-30$ & & & & \\
\hline Rocella gemma & & & 31 & & & & \multirow{4}{*}{ Oligocene } \\
\hline Corbisema spinosa & & \multirow{3}{*}{$-\frac{5-13}{17-20}-$} & $31-33 ?$ & \multirow[b]{3}{*}{$-\overline{1 \mathrm{~A}-4 \mathrm{~A}}$} & & & \\
\hline Dictyocha medusa & & & $34 ?$ & & & & \\
\hline \multirow[b]{2}{*}{ Corbisema hastata-C. apiculata } & & & - & & & & \\
\hline & & \multirow[t]{2}{*}{$\underline{21-24}$} & & \multirow{2}{*}{$\underline{5 A-7 A}$} & \multirow{2}{*}{$14-16$} & $-2-7$ & \multirow{2}{*}{ Eocene } \\
\hline Corbisema hexacantha & & & & & & $8 ?$ & \\
\hline & & & & & & & Unconformity \\
\hline Lyramula furcula & $1-4$ & & & & & & Late Cretaceous \\
\hline
\end{tabular}

TABLE 2

Definitions of Leg 29 Silicoflagellate Zones

\begin{tabular}{|c|c|c|c|}
\hline Age & $\begin{array}{c}\text { Silicoflagellate } \\
\text { Zones and Subzones }\end{array}$ & & Marker Species \\
\hline \multirow[t]{2}{*}{ Pleistocene } & Dictyocha aculeata & & \multirow{2}{*}{$\begin{array}{l}\text { D. aculeata } \\
\text { Paradictyocha }\end{array}$} \\
\hline & Distephanus octogonus & & \\
\hline Pliocene & \multirow{2}{*}{$\begin{array}{l}\text { Paradictyocha } \\
\text { dumitricae }\end{array}$} & \multirow{2}{*}{$\begin{array}{l}-\mathrm{TC} \\
-\mathrm{BC} \\
-\mathrm{BC}\end{array}$} & \multirow{2}{*}{$\begin{array}{l}\text { Mesocena diodon } \\
\text { Paradictyocha }\end{array}$} \\
\hline \multirow{4}{*}{ Miocene } & & & \\
\hline & Distephanus crux & & Naviculopsis \\
\hline & Naviculopsis biapiculata & & N. robusta \\
\hline & Naviculopsis robusta & -TC & R. gemma \\
\hline \multirow{3}{*}{ Oligocene } & Rocella gemma & $-B C$ & R. gemma \\
\hline & Corbisema spinosa & $-B C$ & C. spinosa \\
\hline & Dictyocha medusa & $-\mathrm{T}$ & C. hastata \\
\hline \multirow{2}{*}{$\overline{\text { Eocene }}$} & Corbisema hastata-C. apiculata & $-\mathrm{T}$ & C. hexacantha \\
\hline & Corbisema hexacantha & $-(B$ & C. hexacantha) \\
\hline Unconformity & & -(B & Corbisema hastata \\
\hline Late Cretaceous & Lyramula furcula & B & L. furcula \\
\hline
\end{tabular}

Note: $\mathrm{B}=$ first occurrence $\mathrm{C}=$ common $; \mathrm{T}=$ last occurrence.

Dictyocha is missing while Distephanus is common, indicating temperatures below $5^{\circ} \mathrm{C}$. The relatively higher temperatures in the middle Miocene correlate well with the relatively high diversity and abundance of discoasters found in the same part of the sequence. The suggested high temperature in the late Miocene, however, is not evident in the calcareous nannofossil assemblage. In the poor silicoflagellate assemblage of Pleistocene age at Site 281, D. speculum dominates over the few Dictyocha, suggesting a temperature only a little above $5^{\circ} \mathrm{C}$. The late Miocene assemblage at Site 281 is dominated by Mesocena, with Distephanus and Dictyocha being rare.

For the late Eocene parts of the sequence, higher temperatures, usually around $20^{\circ}-25^{\circ} \mathrm{C}$, are suggested by the Dictyocha/Distephanus ratio in those samples, where a reasonable number of the two genera occur. This correlates well with the findings of Mandra (1969b, 
TABLE 3

Correlations of Silicoflagellate Zones

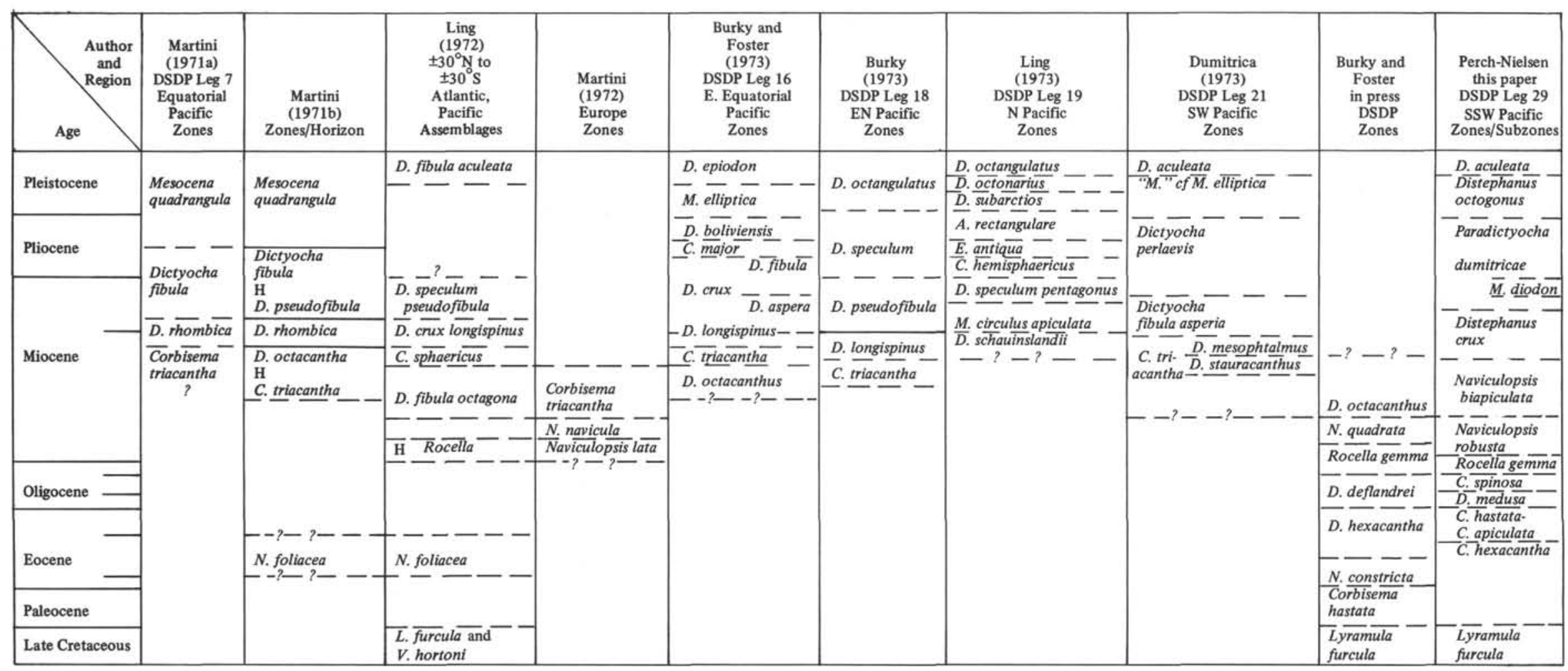

Note: $\mathbf{H}=$ horizon 
TABLE 4

Distribution of Silicoflagellates at Site 278, Late Oligocene to Pleistocene

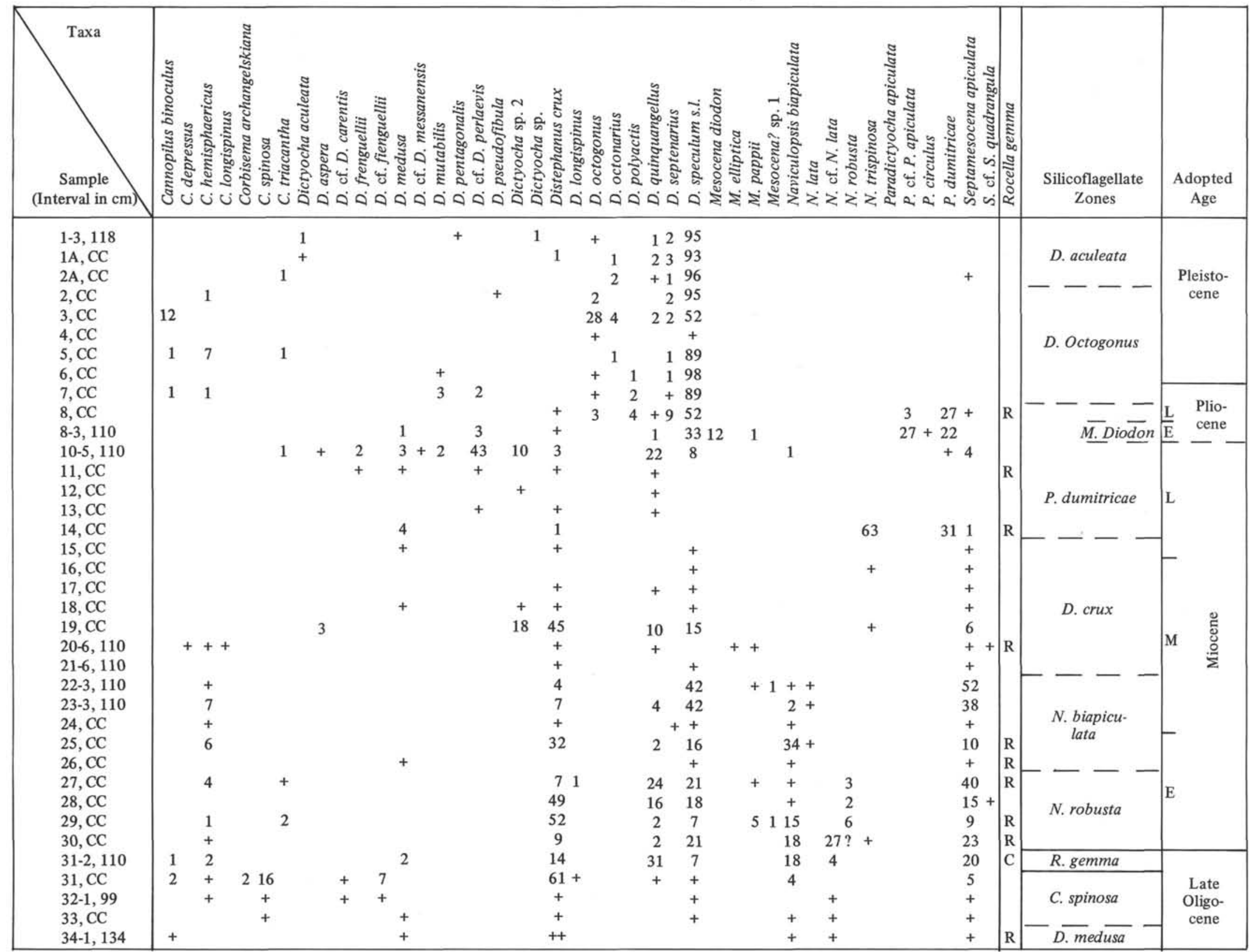

Note: $\mathrm{C}=$ common $\mathrm{R}=$ rare $++=$ present 
TABLE 5

Distribution of Silicoflagellates at Site 281, Late Eocene, Late Miocene, and Pleistocene

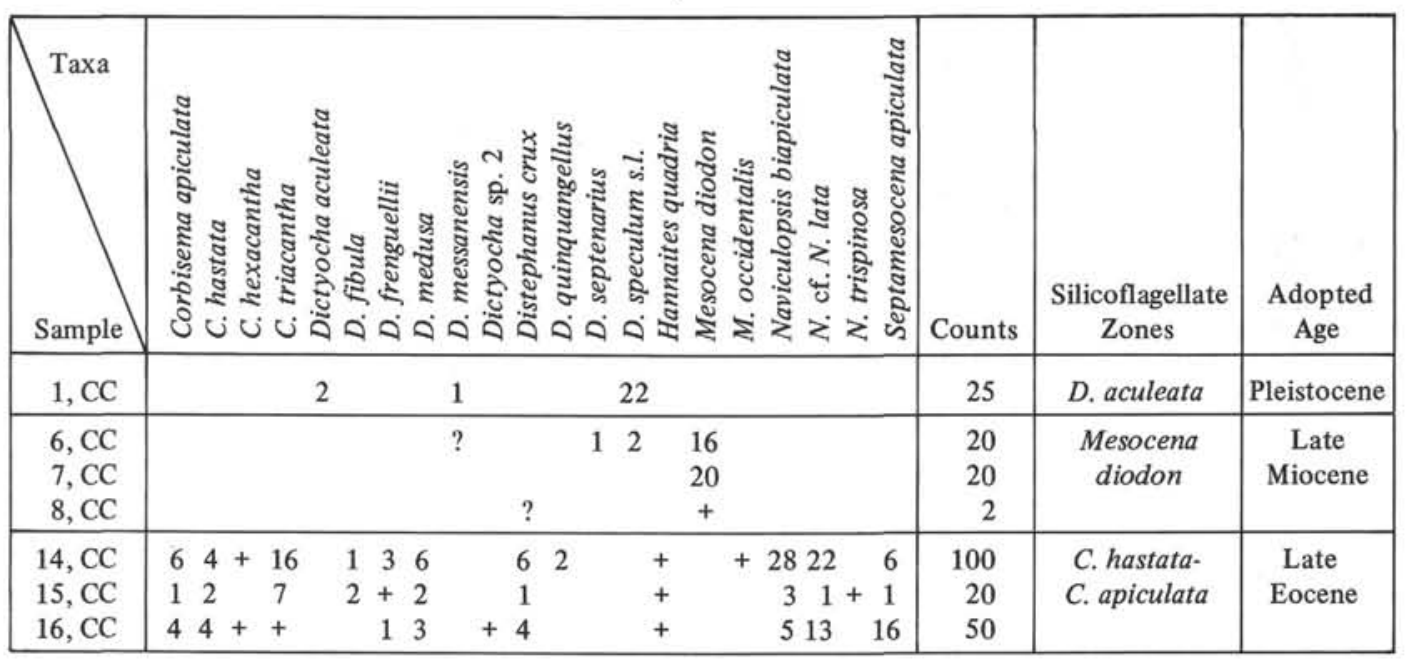

Note: $+=$ present.

TABLE 6

Distribution of Silicoflagellates at Site 277, Late Eocene to Early/Middle(?) Oligocene

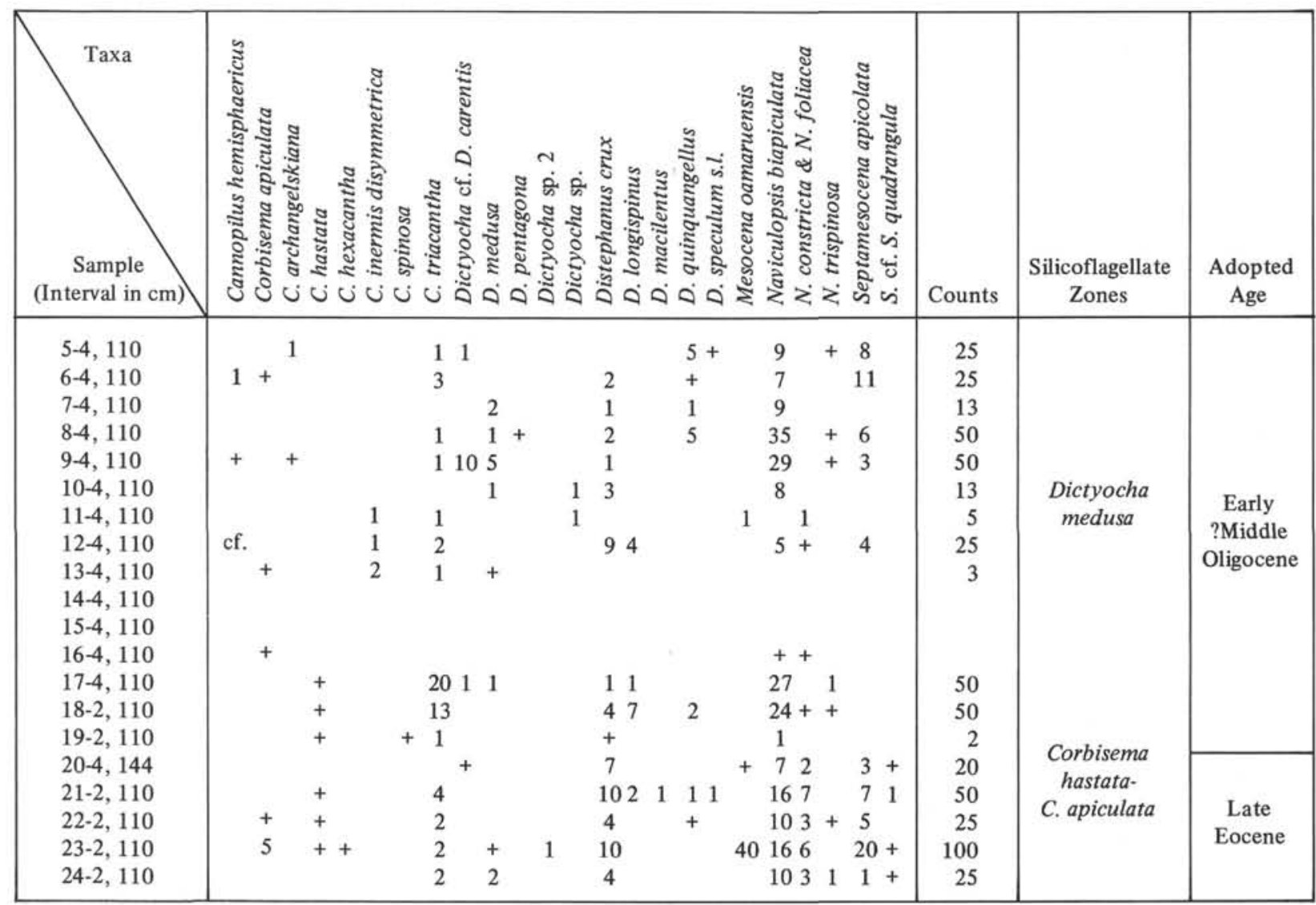

Note $+=$ present. 


\section{K. PERCH-NIELSEN}

TABLE 7

Distribution of Silicoflagellates at Hole 280A, Late Eocene to Early Oligocene

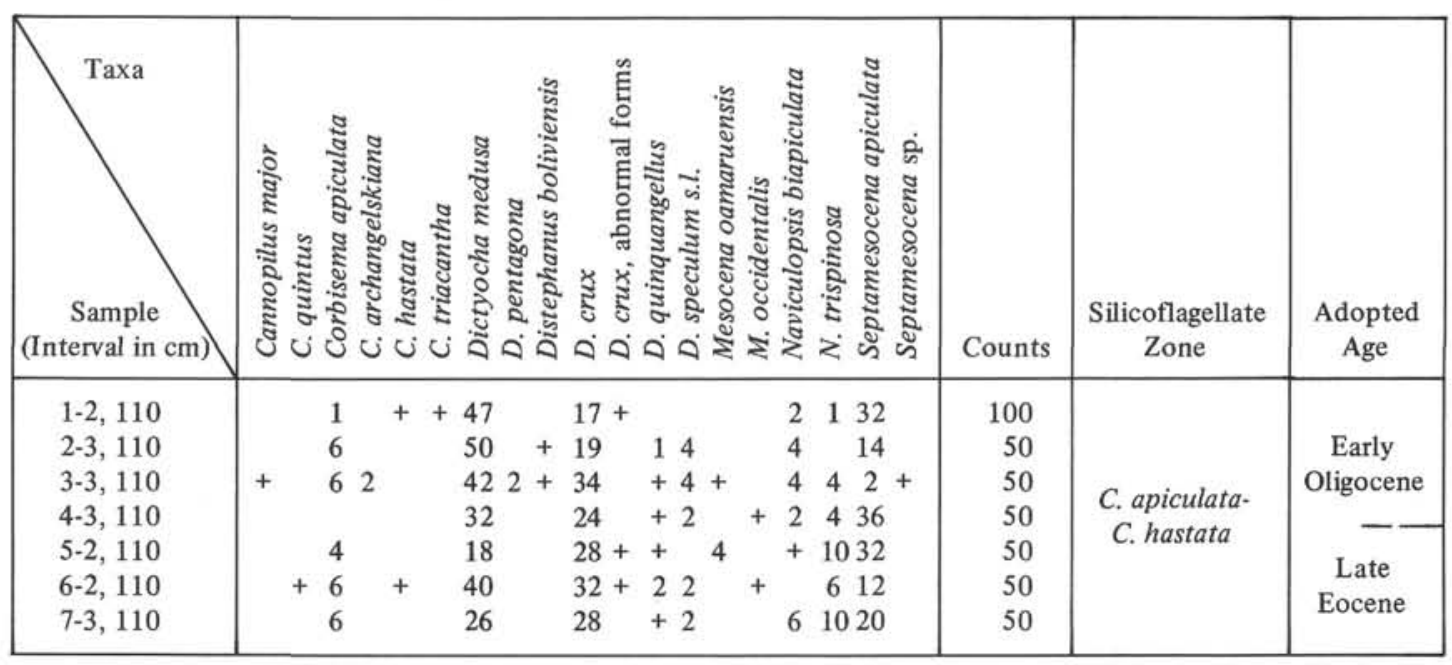

Note: $+=$ present.

TABLE 8

Distribution of Silicoflagellates at Site 283, Late Eocene

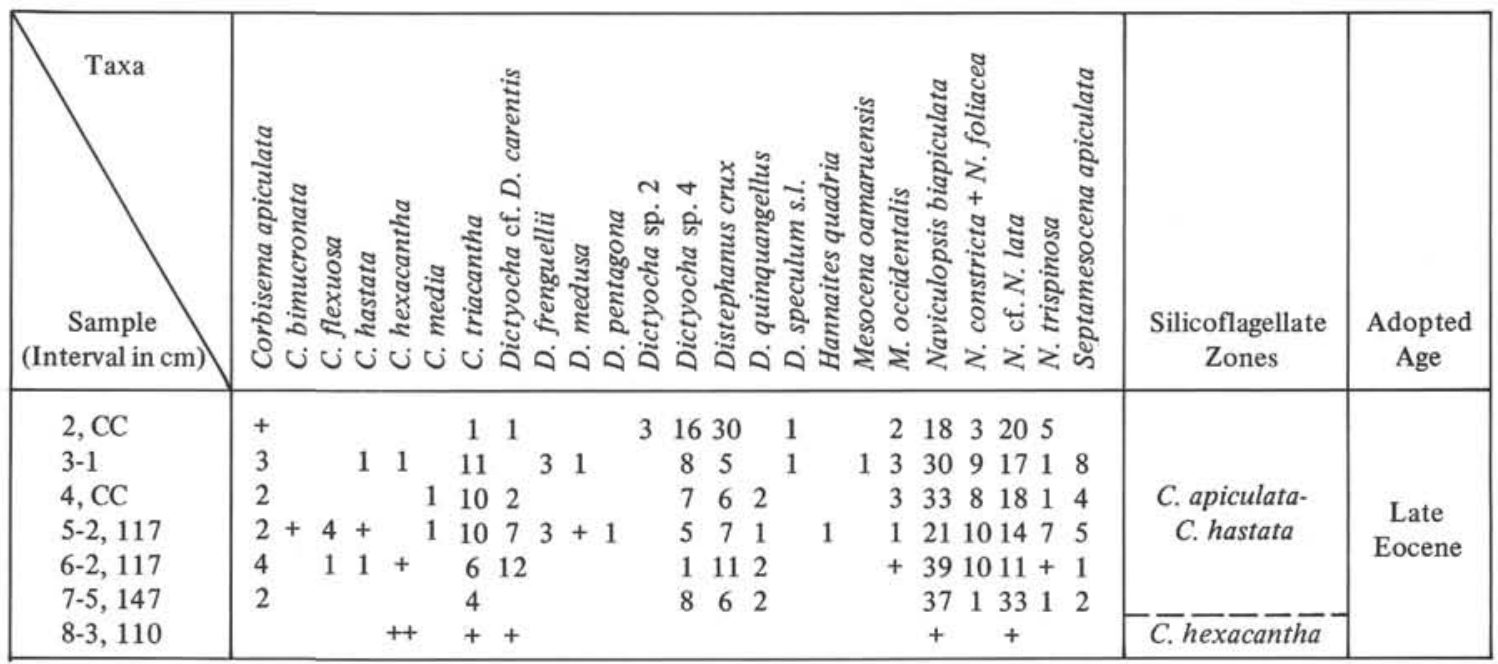

Note: $+=$ present

Mandra and Mandra, 1971, and Mandra et al., 1973) who suggested similar temperatures for the upper Eocene diatomite of Oamaru in New Zealand, and a core at $51^{\circ} \mathrm{S}, 48^{\circ} \mathrm{W}$. For the Oligocene, similar temperatures are suggested for Site 280, while the temperatures seem to have been somewhat lower at Site 277.

\section{Special Conditions}

The amount of irregular skeletal forms in a silicoflagellate assemblage seems to be higher under special conditions, such as low temperatures and low salinities or in coastal waters. This does not seem to be true for assemblages from open ocean areas. The relatively high percentage of misformed silicoflagellates in the late Eocene and early Oligocene of Site $280 \mathrm{might}$ indicate special conditions existed south of Tasmania during the early opening of the ocean between Australia and Antarctica. Irregular skeletons were not found in the late Eocene assemblage of nearby Site 281 which is in shallower water, and has a somewhat older siliceous sequence. Sites 277 and 283 have normal late Eocene silicoflagellate assemblages.

Relatively many irregular skeletal forms were found in Sample 278-19, CC, in the middle Miocene. This sample is the only sample studied from $278-14$, CC, to 278-22, CC rich in silicoflagellates. The sample also shows a Dictyocha/Distephanus ratio, suggesting a relatively high $\left(10-15^{\circ} \mathrm{C}\right)$ temperature for this site. 
TABLE 9

Distribution of Silicoflagellates at Site 275, Late Cretaceous

\begin{tabular}{|c|c|c|c|c|c|}
\hline $\begin{array}{c}\text { Sample } \\
(\text { Interval in } \mathrm{cm})\end{array}$ & 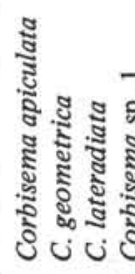 & 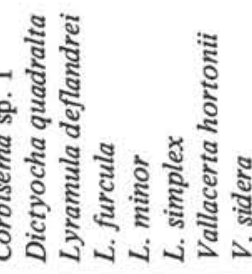 & 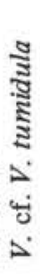 & $\begin{array}{c}\text { Silicoflagellate } \\
\text { Zone }\end{array}$ & Age \\
\hline $\begin{array}{l}1-1,130 \\
1-3,50 \\
1-4,50 \\
1, C C \\
2-2,50 \\
2-3,50 \\
2-4,50 \\
2, C C \\
4-2,50\end{array}$ & 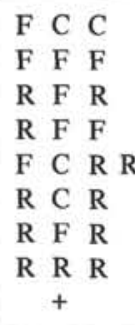 & 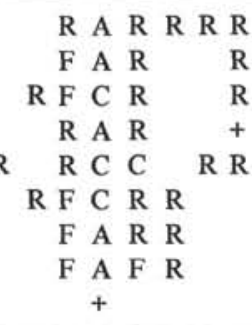 & $\begin{array}{l}+ \\
R \\
R \\
R \\
F \\
R \\
R\end{array}$ & $\begin{array}{l}\text { Lyramula } \\
\text { furcula }\end{array}$ & $\begin{array}{c}\text { Late } \\
\text { Cretaceous }\end{array}$ \\
\hline
\end{tabular}

Note: $\mathrm{A}=$ abundant $\mathrm{C}=$ common $; \mathrm{F}=$ few $; \mathrm{R}=$ rare $;+=$ present.

\section{SILICOFLAGELLATE ZONATION}

Several attempts have been made to use silicoflagellates for biostratigraphy in the few known sections containing silicoflagellates. Recently, as a result of the DSDP, more continuous sections have become available. Martini (1971a) suggested four zones, Bukry and Foster (1973) suggested seven zones for the Miocene to Pleistocene interval of the equatorial Pacific Ocean. For short cores from oceans, land sections, or isolated outcrops, stratigraphic comments were made by Mandra (1968), Hays et al. (1969), Ling (1970, 1971, 1972) and Martini (1972). A comparison of some zonal schemes is given in Table 3 .

The more or less constant and abundant presence of silicoflagellates from the late Oligocene to the Pleistocene at Site $278\left(56^{\circ} \mathrm{S}\right)$ provides a good possibility to check the stratigraphic utility of silicoflagellates in high southern latitudes during the Neogene. Together with the Oligocene sequences at Sites 277 and 280 and the late Eocene at Sites 277, 280, 281, and 283, the zonal scheme can be extended down into the Paleogene. The assemblage at Site 275 represents the Late Cretaceous.

\section{Dictyocha aculeata Zone; Dumitrica (1973)}

The $D$. aculeata Zone is defined by the range of $D$. aculeata (D. epiodon in Bukry and Foster, 1973). It is present in the Pleistocene at Sites 278 and 281, where the assemblage is dominated by Distephanus speculum, with Dictyocha aculeata being very rare. The presence of $D$. aculeata at this high latitude is somewhat surprising, but might be an indication of slightly higher temperatures in the region during the Pleistocene than at present.

\section{Distephanus octogonus Zone}

The base of the $D$. octogonus Zone is defined by the last common occurrence of Paradictyocha; the top, by the first occurrence of D. aculeata. D. octogonus, at Site 278 is common only in one sample studied, but persistently present in the assemblage that is completely dominated by $D$. speculum. Other species sometimes present in low numbers include: Cannopilus binoculus, $C$. hemisphaericus, Dictyocha mutabilis, Distephanus polyactis, D. septenarius, and D. quinquangellus. The D. octogonus Zone includes most of the Pleistocene and late Pliocene at Site 278.

\section{Paradictyocha dumitricae Zone}

The base of the $P$. dumitricae Zone is defined by the first common occurrence of $P$. dumitricae; the top, by the last common occurrence of Paradictyocha. The assemblage includes common to abundant $P$. dumitricae and $P$. apiculata (resp. $P$. cf. $P$. apiculata) and common Distephanus speculum. The dominance of $D$. speculum in the overlying $D$. octogonus Zone does not occur in the $P$. dumitricae Zone and lower, but is replaced by different forms of Paradictyocha. One sample in this interval $(278-10-5,110 \mathrm{~cm})$ is of special interest, as it has a dominance of Dictyocha over Distephanus. This dominance suggests a water temperature of about $25^{\circ} \mathrm{C}$. This is a surprisingly high temperature for a site at $56^{\circ} \mathrm{S}$, even in the late Miocene-early Pliocene. In the same sample Distephanus quinquangellus dominates over $D$. speculum. The samples just above and below Sample 278-10-5, $110 \mathrm{~cm}$ also show relatively high Dictyocha content. Thus, a warmer climate during part of the late Miocene-early Pliocene is probable. This is also supported by a lithologic change from a siliceous ooze above to a diatom-rich nannofossil ooze below. In portions of this nannofossil ooze, silicoflagellates are very rare, but they were found in all decalcified samples. The $P$. dumitricae Zone includes most of the Pliocene, and the late Miocene at Site 278.

\section{Mesocena diodon Subzone}

The $M$. diodon Subzone, which falls within the $P$. dumitricae Zone at Site 278, is defined by the common occurrence of $M$. diodon. It was found in Samples 278-9$1,110 \mathrm{~cm}, 278-9-3,110 \mathrm{~cm}, 278-9-5,110 \mathrm{~cm}, 278-9$, CC, 
and $278-10-2,110 \mathrm{~cm}$ with about $17 \%, 12 \%, 10 \%, 10 \%$, and $5 \% M$. diodon respectively, in the assemblage. The $M$. diodon Subzone occurs in the late Miocene-early Pliocene interval at Site 278, and in the late Miocene at Site 281 . At Site $281, M$. diodon is the dominant species of the assemblage.

\section{Distephanus crux Zone}

The base of the $D$. crux Zone is defined by the last "consistent" occurrence of Naviculopsis; the top, by the first common occurrence of Paradictyocha. In the only sample of this interval at Site 278 where silicoflagellates are common, D. crux dominates the assemblage, and Dictyocha aspera, Dictyocha sp. 2, Distephanus quinquangellus, D. speculum, and Septamesocena apiculata are the other rare to common species. The D. crux Zone occurs in the middle Miocene of Site 278.

\section{Naviculopsis biapiculata Zone}

The base of the $N$. biapiculata Zone is defined by the last occurrence of $N$. robusta; the top, by the last occurrence of "consistent" Naviculopsis. The common species in this assemblage are $N$. biapiculata, Distephanus speculum, and Septamesocena apiculata, while Cannopilus hemisphaericus, D. crux, D. quinquangellus, and Naviculopsis lata occur occasionally. This zone was found in the late early, and early mid Miocene of Site 278.

\section{Naviculopsis robusta Zone}

The base of the $N$. robusta Zone is defined by the last common occurrence of Rocella gemma; the top, by the last occurrence of $N$. robusta. The silicoflagellate assemblage is quite similar to that of the $N$. biapiculata Zone, but $D$. quinquangellus is relatively more frequent in this zone, compared to $D$. speculum than in the younger zone, and Corbisema triacantha is present in two samples. The $N$. robusta Zone was found in the early early Miocene at Site 278.

\section{Rocella gemma Zone}

The $R$. gemma Zone includes the interval with common $R$. gemma. The rest of the assemblage is very similar to the assemblages of the overlying two zones, without $N$. robusta. $R$. gemma occurs both higher up and further down in the sequence at Site 278 , but is always rare, even just above the sample $(278-31-2,110 \mathrm{~cm})$ with common $R$. gemma. $R$. gemma is known to occur in great numbers around the Oligocene-Miocene boundary, and this is true at Site 278.

\section{Corbisema spinosa Zone}

The base of the $C$. spinosa Zone is defined by the first more or less common occurrence of $C$. spinosa; the top, by the first common occurrence of Rocella gemma. Only one sample $(278-31, \mathrm{CC})$ at Site 278 includes a wellpreserved silicoflagellate assemblage belonging to this zone. Here, the dominant species is Distephanus crux; $C$. spinosa is common, and Dictyocha cf. D. frenguellii, Cannopilus binoculus, and Naviculopsis biapiculata occur rare to few, as does Septamesocena apiculata. In Samples 278-32-1, $99 \mathrm{~cm}$, and 278-33, CC the siliceous microfossils are very poorly preserved, usually broken. $C$. spinosa is still present, but no counts were made. The $C$. spinosa Zone was found in the late Oligocene, only at Site 278 , the only site where sediments with siliceous microfossils of late Oligocene age were recovered.

\section{Dictyocha medusa Zone}

The $D$. medusa Zone includes the interval from the last occurrence of Corbisema hastata s.l. (including also the forms smaller than typical $C$. hastata and with a straight base-line) to the first occurrence of common Corbisema spinosa. D. medusa is more or less consistently present in the relatively poor assemblages found belonging to this zone at Site 277. The assemblages are dominated by Naviculopsis, and include also Distephanus crux, Corbisema triacantha, Distephanus longispinus, D. quinquangellus, and Septamesocena apiculata. The $D$. medusa Zone was found in the (?)early to middle? Oligocene of Site 277.

\section{Corbisema hastata-C. apiculata Zone}

The Corbisema hastata-C. apiculata Zone includes the interval from the last occurrence of Corbisema hexacantha to the last occurrence of Corbisema hastata. Throughout this interval, $C$. hastata and/or C. apiculata are present in low numbers. The assemblage in this zone is dominated by Naviculopsis at Sites 277, 281, and 283, and by Dictyocha medusa, Distephanus crux, and Septamesocena apiculata at Site 280. The $C$. hastata- $C$. apiculata Zone spans the Eocene-Oligocene boundary at Sites 277 and 280, and includes the late Eocene at Site 283. The late Eocene assemblage at Site 281 includes only very rare $C$. hexacantha, and is therefore also assigned to the $C$. hastata-C. apiculata Zone. Naviculopsis trispinosa is present in most samples in this zone, but rare specimens also occur higher up in the Oligocene, and even into the early Miocene.

\section{Corbisema hexacantha Zone; Bukry and Foster (in press)}

The base of this zone was not found in the material collected on Leg 29 . It is only represented in the early late Eocene of Site 283, where $C$. hexacantha is relatively common in Sample 2833, $110 \mathrm{~cm}$.

\section{Middle Eocene to Paleocene}

No sediments of middle Eocene to Paleocene age including silicoflagellates were found on Leg 29.

\section{Lyramula furcula Zone; \\ Bukry and Foster (in press)}

The L.furcula Zone is the only Late Cretaceous zone described to the present time, and thus includes all Late Cretaceous assemblages found. These vary greatly in the quantitative distribution of the species, but little in the qualitative distribution of the species. The L. furcula Zone has been correlated with the calcareous nannofossil zone of Nephrolithus frequens which is of late Maestrichtian age at DSDP Site 216. At Site 275, the assemblage of the L. furcula Zone includes common to abundant $L$. furcula, few to common Corbisema geometrica and $C$. lateradiata, and rare to few $C$. apiculata Dictyocha quadralta (forms with 4-6 sides), Lyramula deflandrei L. minor, L. simplex, Vallacerta hortonii, $V$. sidera, and $V$. cf. tumidula. 


\section{SYSTEMATIC PALEONTOLOGY}

In the following, no attempt has been made to present synonymy lists for the species used in this report. Instead, the illustrations given on Plates 1-15 demonstrate the content adopted for the different species.

\author{
Genus CANNOPILUS Haeckel, 1887 \\ Cannopilus depressus (Ehrenberg) n. comb. \\ (Plate 1, Figures 1-5) \\ Halicalyptra depressa Ehrenberg, \\ 1854, Pl. 18, fig. 110
}

Remarks: $C$. depressus is rare in some mid-Miocene samples of Site 278. The apical spines have about the same length as the radial spines and the size and number of apical windows varies considerably. From the description and the illustrations of $C$. picassoi Stradner, the latter has more and smaller apical windows than $C$. depressus.

\section{Cannopilus hemisphaericus (Ehrenberg) Haeckel 1887}

$$
\text { (Plate 1, Figures 10-12) }
$$

Remarks: Only few specimens of this small, 6-sided form of Cannopilus with a varying number of apical windows were found in the mid Miocene of Site 278.

\section{Cannopilus major (Frenguelli) \\ Bukry and Foster 1973}

(Plate 1, Figure 6)

Remarks: A single specimen of $C$. major was found in the Oligocene of Site 280 . The specimen has seven radial spines, and an apical net with windows of varying size.

\section{Cannopilus quintus Bukry and Foster 1973}

(Plate 1, Figures 8,9)

Remarks: Very few specimens of this pentagonal form of Cannopilus were found and were assigned to $C$. quintus. In their description, Bukry and Foster (1973) noted an apical ring with four asymmetric openings. The mid-Miocene specimen found here shows three larger and two very small apical windows. Two apical windows of different size were found in an Oligocene specimen. C. quintus was described from the late Pliocene of the Panama Basin.

\section{Genus CORBISEMA Hanna 1928 a,b}

Corbisema apiculata (Lemmermann) Hanna 1931

(Plate 2, Figures 15, 16, 19; Plate 3, Figures 19, 20, 24;

$$
\text { Plate 15, Figures 1,2) }
$$

Remarks: C. apiculata was originally described from the Paleocene and was found in the Late Cretaceous of Site 275, in the Eocene and Oligocene of different sites. It was not found in the Neogene. $C$. apiculata varies considerably in size and outline as well as in length and position of the sustaining spines. Three slightly different forms can be distinguished in the Late Cretaceous assemblage. The largest form (Plate 2, Figure 15) bears only short, vertical sustaining spines. The smallest, somewhat rounded form, also bears short, but obliquely oriented sustaining spines (Plate 2, Figure 19). In both cases, these spines are attached at the same place as the lateral rods. In the third form, however, the long and bent sustaining spines are attached beside this junction (Plate 2, Figure 16). In the Paleocene forms described by Lemmermann (1901), the sustaining spines are long, more or less oblique, and attached at the junction of the basal body ring and lateral rods as in the late Eocene and Oligocene forms illustrated (Plate 3, Figures 19, 20,24). The Oligocene specimen shows a bifurcation of the sustaining spines.

\section{Corbisema archangelskiana \\ (Schulz) Frenguelli 1940 \\ (Plate 3, Figures 17, 22)}

Remarks: Few specimens without radial spines were found of this large species. Originally described from the Late Cretaceous and Paleocene, it occurs as late as the late Oligocene in the southeast Pacific.

\section{Corbisema bimucronata Deflandre 1950}

(Plate 3, Figure 9)

Remarks: Only a single specimen of $C$. bimucronata was found in the late Eocene of Site 283. C. bimucronata was originally described from the late Eocene of Barbados.

Corbisema flexuosa (Stradner) n. comb.

(Plate 3, Figure 10)

Corbisema triacantha var. flexuosa Stradner 1961, p. 89, fig. 1-8; fig. 1C

Remarks: From the Austrian Chattian (Oligocene), Stradner (1961) described both smaller and larger forms of his variation. The small forms do not show the typical concaveness of the sides of the triangle, or the slight asymmetrical orientation of the lateral rods. C. flexuosa is rare in the late Eocene of Site 283.

\section{Corbisema geometrica Hanna 1928}

(Plate 2, Figures 1-6, 8)

Remarks: Large and small specimens with an apical plate as illustrated on Plate 2 are considered as $C$. geometrica. They usually have no radial spines at all, but one specimen shows a thinning of the silica at the place where a spine would be. Some specimens have a flat basal body ring, while it is strongly bent in others. The outline varies somewhat, due to rounded lateral windows to more rectangular ones. C. geometrica was originally described from the Late Cretaceous, and is not rare in the Late Cretaceous of Site 275.

\section{Corbisema hastata (Lemmermann) Frenguelli 1940 \\ (Plate 3, Figures 2-4, 8, 21; Plate 15, Figure 3)}

Remarks: The specimens found of this species differ somewhat from the specimens illustrated by Lemmermann (1901) from the early Eocene of Denmark. In the latter the base line of the triangle is more convex than in the specimens illustrated from the Eocene of Sites 277, 280 , and 283.

\section{Corbisema hexacantha Deflandre 1950}

(Plate 3, Figures 13, 14)

Remarks: This hexagonal species with a trigonal apical structure was originally described from the late Eocene of Oamaru, New Zealand, and is not rare in samples of comparable age in Sites 281 and 283 , but is very rare in the late Eocene of Site 277 . It seems to be restricted to the late Eocene, and (?)Early Oligocene (Ling, 1972).

\section{Corbisema inermis disymmetrica Dumitrica 1973}

(Plate 8, Figures 1, 2)

Remarks: Only a few specimens were found of this robust subspecies described recently by Dumitrica (1973) from the early to mid Paleocene of Site 208 (see Figure 1). They occur in the Oligocene of Site 277 in two samples, where other silicoflagellates are rare, and in another one where they are not rare. They could be reworked; however, no other silicoflagellates suggesting reworking were found. No transitional forms towards a triangular form were found.

\section{Corbisema cf. C. lamellifera hastata (Glezer) n. comb. \\ (Plate 3, Figure 18)}

Dictyocha lamellifera Glezer var. hastata Glezer 1964 (pl. 35, fig. 15 in Loeblich et al., 1968)

Remarks: The single specimen illustrated (Plate 3, Figure 18) was found in the late Eocene of Site 277, while C. lamellifera hastata was originally described from the early Eocene. The forms are similar in the flat, broad apical structure, and in the presence of flat triangular sustaining spines at the two sidelines of the triangle, while a spine seems to be missing on the base of the triangle. The specimen illustrated here differs from Glezer's (1964) in that the base of the triangle is more concave, and the adjacent two radial spines are parallel to the median. Also in our specimen all radial spines are shorter, and the form of the apical windows differ from each other. 
Corbisema lateradiata (Schulz) n. comb. (Plate 2, Figures 7, 10, 11, 17, 18)

Dictyocha triacantha Ehrenberg var. apiculata Lemmermann forma late-radiata Schulz 1928 , p. 281,282 , fig. 73

Remarks: This species of Corbisema, with small radial spines, with or without small sustaining spines, and with an apical plate, is the most common Corbisema in the Late Cretaceous of Site 275. No specimens with long radial spines such as those in the Tertiary $C$. triacantha were found. The forms vary considerably in size. C. lateradiata seems to be restricted to the Late Cretaceous.

\section{Corbisema media (Glezer) n. comb.}

(Plate 3, Figures 5, 6)

Dictyocha elata var. media Glezer 1964, p. 51

Remarks: Besides the larger species of Corbisema, these small forms rarely occur in the late Eocene of Site 283 . They were originally described from (?)early Oligocene of the USSR. The radial spines are very small or missing. Without a study of the original material, it is impossible to differentiate the forms any further.

\section{Corbisema minor (Schulz) n. comb.}

(Plate 3, Figures 7, 12)

Dictyocha triacantha f. minor Schulz 1928, p. 247, fig. 25a, b, 26

Remarks: This species was originally described from the early Eocene of Denmark. C. minor differs from C. triacantha only by its shorter radial spines, and more compact, less elegant appearance. It occurs here in the late Eocene of several sites.

\section{Corbisema spinosa Deflandre 1950}

$$
\text { (Plate 3, Figure 23) }
$$

Remarks: C. spinosa was first described from the Eocene diatomite from Barbados. It occurs in the late Oligocene of Site 278 where it is not true.

\section{Corbisema triacantha (Ehrenberg) Hanna 1931}

(Plate 3, Figures 11, 15, 16)

Remarks: In C. triacantha the radial spines are long and the sides of the triangle slightly convex. In Paleogene specimens, the lateral rods tend to originate nearer to one edge of the triangle than the other. In the Miocene specimens (Plate 3, Figure 16), the lateral rods originate in the middle of the sides of the triangle.

Corbisema sp. 1

(Plate 2, Figure 12)

Remarks: A few specimens of this "open" Corbisema were found in the Late Cretaceous of Site 275.

\section{Corbisema sp. 2}

(Plate 3, Figure 1)

Remarks: A single specimen of a strongly bent form of Corbisema was found in the Oligocene of Site 280 (Hole 280A).

\section{Genus DICTYOCHA Ehrenberg 1837 \\ Dictyocha aculeata Lemmermann 1901 \\ (Plate 5, Figures 3,4)}

Remarks: D. aculeata has a quadrate to octagonal basal ring with four prominent and four minor radial spines. The apical bar is oriented parallel to the axis. This species has been reported by Bukry and Foster (1973) as D. epiodon, from Pleistocene samples of the north as well as the equatorial Pacific. Its occurrence in the Pleistocene of Site 281 and 278 at $48^{\circ} \mathrm{S}$ and $56^{\circ} \mathrm{S}$, underlines its wide distribution. The specimens described by Lemmermann (1901) have a vertical apical spine attached to the apical bar. This is missing in the forms found here as well as those illustrated by Bukry and Foster (1973) and Ling (1972). Our specimens also resemble the Recent Dictyocha antarctica Lohmann which is, however, built more irregularly.

\section{Dictyocha aspera (Lemmermann) \\ Bukry and Foster 1973 \\ (Plate 4, Figures 9, 10, 15)}

Remarks: D. aspera includes forms with curved sides, short radial spines often of slightly different length, and an apical bar usually parallel to the shorter axis. Sustaining spines are present, or missing. D. aspera is not rare in "warm" Miocene, and Pliocene samples of Site 278.

$$
\text { Dictyocha ef. D. carentis (Glezer) n. comb. }
$$$$
\text { (Plate 4, Figures 1, 6, 7) }
$$

Dictyocha frenguellii Deflandre var. carentis Glezer forma carentis Glezer 1964 (Pl. 35, fig. 3-5 in Loeblich et al. 1968)

Remarks: This small, compact Dictyocha has two pairs of spines of different length, the longer ones standing vertical to the apical bar. There are only rudimentary sustaining spines, if any. D. carentis was originally described from the late Eocene of the U.S.S.R., and occurs in the late Eocene of several sites. An abnormal form was found in the late Oligocene of Site 278.

\section{Dictyocha fibula Ehrenberg 1839 (Plate 5, Figure 5)}

Remarks: In this paper, D. fibula includes only large forms with a curved basal ring, and an apical bar parallel to the longer axis. It is rare in the late Eocene of Site 281.

\section{Dictyocha frenguellii Deflandre 1950 \\ (Plate 4, Figures 14, 17; Plate 5, Figure 1)}

Remarks: The holotype of $D$. frenguellii is a quadrangular specimen with an H-shaped rather than an X-shaped apical structure. Similar triangular forms, therefore, are described as Corbisema spinosa Deflandre. $D$. frenguellii was originally described from the Eocene of the USSR, and was found in the late Eocene of Sites 281 and 283.

\section{Dictyocha cf. D. frenguellii Deflandre 1950 (Plate 5, Figures 7, 8)}

Remarks: In the late Oligocene of Site 278, a few specimens of a form very similar to $D$. frenguellii were observed together with Corbisema spinosa. It differs from the latter by its X-shaped, rather than $\mathrm{H}$-shaped apical structure, and is smaller than the late Eocene specimens of $D$. frenguellii.

\section{Dictyocha medusa Haeckel 1887}

(Plate 4, Figures 4, 5; Plate 15, Figures 5-7)

Remarks: A variety of more or less quadrate, small forms with a simple, X-shaped apical structure represents this species. Graduations towards Distephamus crux, Dictyocha aspera, and D. minor are common and listed under $D$. medusa.

\section{Dictyocha messanensis Haeckel 1862}

(Plate 5, Figures 13, 14)

Remarks: Silicoflagellates corresponding to the species concept of D. messanensis as given by Ling $(1970,1972)$, and without apical or sustaining spines were found in the Pleistocene of Site 281, where they are not rare. The species is restricted to the Pleistocene and Recent.

\section{Dictyocha cf. D. messanensis Haeckel 1861 (Plate 5, Figures 2, 6)}

Remarks: The only difference between the forms assigned to $D$. messanensis and $D$. cf. messanensis is the slight angle with which the apical bar stands to the major axis in D. cf. messanensis. The distinction is made here because of the different stratigraphic levels in which the two forms occur. D. messanensis seems to be limited to the Pleistocene and Recent, while $D$. cf. messanensis occurs in the Miocene of Site 278.

\section{Dictyocha mutabilis Deflandre 1950 (Plate 4, Figure 13)}

Remarks: The specimen of this species illustrated here is almost identical with the illustration of the holotype and other typical forms of the species described from the middle Miocene of California. No forms similar to the "navicular forms" of the species were found. Deflandre (1950), admits that the difference between D. mutabilis and $D$. ausonia is not very distinct. Judging from the illustrations of the holotypes, the axes have a greater difference in length in $D$. mutabilis than in D. ausonia. 


\section{Dictyocha pentagona (Schulz)}

Bukry and Foster 1973

(Plate 5, Figure 11; Plate 15, Figure 4)

Remarks: Schulz (1928), illustrated and described two rather different specimens under this name. He first describes a specimen from the early Eocene of Denmark, and then a "related form" from the Pleistocene of the Baltic Sea. The rare specimens found in the late Eocene of the southeast Pacific are conspecific with Schulz's Eocene specimen.

\section{Dictyocha pentagonalis \\ (Aurivillius) n. comb. \\ (Plate 5, Figure 12)}

Dictyocha fibula var. pentagonalis Aurivillius 1898, p. 53, fig. 15

Remarks: A single specimen of this species was found in the late Pleistocene of Site 278. It was originally described from the Gullmarfjord in Norway. D. pentagonalis has a short apical spine and a slender skeleton, while $D$. pentagona lacks an apical spine and has a relatively thicker skeleton.

\section{Dictyocha cf. D. perlaevis Frenguelli 1951}

(Plate 5, Figures 9, 10, 16, 17)

Remarks: D. perlaevis was described from the Miocene of Chile. The forms here assigned to $D$. cf. $D$. perlaevis, sometimes have longer apical spines. The apical bar lies parallel to the long axis, and the basal ring is less curved than in the original specimens. D. cf. D. perlaevis is rare to common in the Miocene of Site 278.

\section{Dictyocha pseudofibula \\ (Schulz) Tsumura 1963}

(Plate 5, Figure 15)

Remarks: A single specimen of this small species was found in the Pleistocene of Site 278. The single occurrence is surprising at this high latitude site, where this cool-water form was expected to be more common.

\section{Dictyocha quadralta Hanna 1928}

(Plate 2, Figures 9, 13, 14; Plate 9, Figures 22, 23, 28)

Remarks: Large quadrangular, pentagonal, and hexagonal forms, occurring sporadically in the Late Cretaceous of Site 275 , are assigned to the originally quadrangular $D$. quadralta. None of them have sustaining spines, but all have sharply pointed radial spines. The quadrangular forms, especially, are difficult to distinguish from Tertiary Dictyocha, which are usually smaller. D. quadralta has been found in different Upper Cretaceous sediments including an Arctic Ocean core (Ling, 1973).

\section{Dictyocha sp. 1}

(Plate 4, Figure 8)

Remarks: This specimen shows slightly concave sides leading to small angles in the four corners of the large silicoflagellate. The radial spines are short, and the apical bar is transverse to the longer axis of the body. It occurs in the late Miocene of Site 278.

\section{Dictyocha sp. 2}

(Plate 4, Figures 11, 12)

Remarks: Specimens with straight sides, an apical bar of varying length, and no sustaining spines occur sporadically from the late Eocene to the early Pliocene.

\section{Dictyocha sp. 3 \\ (Plate 4, Figure 16)}

Remarks: Almost quadratic, large forms with a central cross, and sustaining spines attached beside the junction of the lateral rods with the basal body ring, are rare in the early Miocene of Site 278 .

Dictyocha sp. 4

(Plate 5, Figure 18)

Remarks: Like Dictyocha sp. 3, this form has an X-to H-shaped apical structure and sustaining spines attached beside the junction of the lateral rods with the basal body ring. But in Dictyocha sp. 4, the body is smaller in relation to the length of the spines, and the form appears more compact.
Dictyocha? sp. 5

(Plate 8, Figures 3, 4)

Remarks: A single specimen of this partly broken, crenulate silicoflagellate skeleton was found in the late Eocene of Site 281. It consists of a \pm quadrangular basal body ring, with radial spines. A second, broken apical ring with apical spines rests on vertical lateral rods.

\section{Dictyocha? sp. 6 \\ (Plate 8, Figure 6)}

Remarks: A single, broken specimen of this extremely large form was found in the Oligocene of Site 277 . The basal body ring is very thick, and includes a large channel. The radial spines are not very distinct. The outline of the form is probably hexagonal. Two lateral rods join together, to form a triangular apical bar.

\section{Genus DISTEPHANUS Stöhr 1880 \\ Distephanus boliviensis (Frenguelli) \\ Bukry and Foster 1973 \\ (Plate 6, Figures 10, 11)}

Remarks: D. boliviensis includes the large specimens of $D$. speculum like silicoflagellates. It occurs here sporadically in the Oligocene of Site 280.

Distephanus crux (Ehrenberg) Haeckel 1887

(Plate 6, Figures 1, 4, 7: abnormal forms.

Plate 6, Figures 2, 3, 5: large forms. Plate 7,

Figures 1-5, 7-10, 13: s.l. Plate 15, Figure 8.)

Remarks: No attempt has been made to distinguish different species or variants within D. crux s.l.

Abnormal assemblages of large $D$. crux with quadrangular, almost round, and pentagonal outline occur in the Oligocene of Site 280. Some of them have sustaining spines, and some also have apical spines. The lateral rods are typically bent. The apical window has an irregular form, and sometimes is subdivided by apical spines.

In the same samples large "normal" $D$. crux occur, with a quadrangular outline, straight lateral rods, and with or without sustaining spines. The size of the apical window varies considerably, as does the length of the radial spines.

Smaller forms, but still larger than $D$. parvus, are assembled regardless of the size relations of outline, and apical window. The size of the latter varies considerably, while the size of the outline seems more constant. Sustaining spines are usually absent. The form of the apical window is round, quadrangular, quadrangular with concave sides, or triangular in irregular forms.

\section{Distephanus longispinus (Schulz) n. comb.} (Plate 6, Figure 6)

Distephanus crux (Ehrenberg) Haeckel f. longispina Schulz 1928, p. 256, fig. 44

Remarks: D. longispinus was described from the Miocene (Helvetian) of California. It occurs sporadically in the late Oligocene of Site 278.

Distephanus macilentus (Deflandre) n. comb.

(Plate 7, Figure 6)

Dictyocha macilenta Deflandre 1950, p. 198, fig. 211-218.

Remarks: Only a single specimen of this species, originally described from the Miocene of Hungary, was found in the late Oligocene of Site 278 .

\section{Distephanus octogonus (Ehrenberg) Dumitrica 1972 (Plate 7, Figures 19, 20; Plate 11, Figures 2-4)}

Remarks: In the samples of Pleistocene age from Site 278, rare to common $D$. octogonus were found. Most of them have nine, some eight radial horns; some forms have an apical apparatus still preserved, although most have lost it. D. octogonus is considerably smaller than $D$. polyactis, or the mesocenoid forms Paradictyocha apiculata, and $P$. dumitricae.

\section{Distephanus octonarius (Ehrenberg) n. comb.} (Plate 1, Figure 13)

Dictyochia octonaria Ehrenberg 1844, p. 186, 201.

Remarks: This octagonal form is very rare in the Pleistocene samples studied from Site 278 in the southwestern Pacific. 


\section{Distephanus polyactis (Ehrenberg)}

Deflandre 1932b

(Plate 7, Figure 12; Plate 11, Figure 11)

Remarks: Dumitrica (1973) has discussed the content of D. polyactis, and his definition is followed here. The stratigraphic distribution indicated by Dumitrica (1973) for the southwest Pacific is, however, different from the one found here. He observed $D$. polyactis in the middle and late Miocene at DSDP Site 206, and in the late Miocene at DSDP Site 205 (see Figure 1). At Site 278, it is very rare in the late Pliocene and in the early Pleistocene.

\section{Distephanus quinquangellus Bukry and Foster 2973 \\ (Plate 6, Figures 8, 9; Plate 7, Figures 11, 14, 15)}

Remarks: $D$. quinquangellus is rare to common from the Oligocene to the Pleistocene of Sites 277, 278, and 280. In this report specimens with sustaining spines were grouped together with those without such spines, and forms with apical spines. The overall size, the size of the apical window, and the length of the radial spines vary considerably. In the $>60 \mu$ fraction of Sample 278-20-6, $130 \mathrm{~cm}$ abnormal forms of $D$. quinquangellus with six radial spines but only five lateral rods and a pentagonal apical window are not rare.

\section{Distephanus septenarius \\ (Ehrenberg) n. comb. \\ (Plate 7, Figures 21, 22)}

Dictyocha septenaria Ehrenberg 1844, p. 64, 80

Remarks: This 7-cornered form occurs only occasionally. It was counted separately from the 6-cornered form $D$. speculum to allow eventual later environmental studies from the differences in frequencies of the 5-, 6-, and 7-cornered forms.

\section{Distephanus speculum s.I.}

(Ehrenberg) Haeckel 1887

(Plate 6, Figure 12, 13; Plate 7, Figures 16-18, 23)

Remarks: The species concept proposed by Ling (1972), and Bukry and Foster(1973), of D. speculum includes only those hexagonal forms with two prolonged and four smaller radial spines. Such forms are rare and were only found in the late Oligocene, and early Miocene of Site 278. The more common forms with six more or less equal spines are here included in $D$. speculum. This species is by far the most common form in the Pliocene and Pleistocene of Site 278, and in the Pleistocene of Site 281. In older sediments its frequency varies, but never reaches over $50 \%$ and usually is much rarer.

\section{Distephanus sp. 1}

(Plate 8, Figure 11)

Remarks: This more or less quadrate form might represent an abnormal specimen of D. crux s.l. It was found in the late Eocene of Site 277.

\section{Genus HANNAITES Mandra 1969a \\ Hannaites quadria Mandra 1969a \\ (Plate 8, Figures 9, 10, 12-14)}

Remarks: Several specimens of this species described and thus far only known from the Eocene of a South Atlantic deep-sea core, were found in different samples of the late Eocene of Sites 281 and 283.

$$
\begin{gathered}
\text { Genus LYRAMULA Hanna 1928b } \\
\text { Lyramula deflandrei Perch-Nielsen } \\
\text { and Edwards n. sp. } \\
\text { (Plate 9, Figures 8-17) }
\end{gathered}
$$

Holotype: Plate 8, Figure 9.

Type locality: DSDP Site 275, southwest Pacific.

Description: To the basically Y-shaped form is added a "third leg" on one of the long arms. Its length is similar to the length of the leg to which it is attached.

Remakrs: $L$. deflandrei differs from $L$. furcula and $L$. minor, through the presence of a third leg. Additional legs also occur.

Occurrence: $L$. deflandrei is rare to common in the samples of Late Cretaceous age of Site 275 in the southwest Pacific. Similar forms were included by Deflandre (1940), and later others in L. furcula var. minor. and reported from the Late Cretaceous.
Lyramula furcula Hanna 1928b

(Plate 9, Figures 18-21, 26, 27)

Remarks: $L$. furcula shows a considerable variation in size and shape of the Y-shaped body. It is the most common of the species of Lyramula in the Late Cretaceous samples of Site 275.

\section{Lyramula minor (Deflandre) Deflandre 1950 (Plate 9, Figures 17)}

Remarks: L. minor is usually smaller than $L$. furcula, and the two longer arms of the Y-shaped body almost form a circle. Deflandre (1940) also included forms with additional spines in his L. furcula var. minor. These are separated here and $L$. deflandrei $\mathrm{n}$. sp. is erected to include the forms with three or more legs. L. minor occurs together with $L$. furcula, but is less frequent in the Late Cretaceous samples of Site 275 .

\section{Lyramula simplex Hanna 1928b}

(Plate 9, Figures 24, 25)

Remarks: Only very few specimens of this simple form were found in the Late Cretaceous of Site 275.

\section{Genus MESOCENA Ehrenberg 1843 \\ Mesocena diodon Ehrenberg 1844 \\ (Plate 10, Figure 1)}

Remarks: Typical specimens of $M$. diodon with only two radial horns, as well as forms with an additional, smaller spine, were found. $M$. diodon is rare to common in upper Miocene to (?)lower Pliocene samples of Site 278, and upper Miocene samples of Site 281.

\section{Mesocena elliptica (Ehrenberg) \\ Ehrenberg 1844 \\ (Plate 10, Figures 14, 19, 21-24)}

Remarks: The shape of the body ring and the number of spines varies considerably in $M$. elliptica. The surface of the body ring is smooth or ornamented. Unlike in low latitudes, $M$. elliptica was not found in Pleistocene samples, but is common in the $>63 \mu$ fraction of the mid Miocene of Site 278. Pentagonal forms (Plate 10, Figure 14) are especially common in the $>63 \mu$ fraction of the mid Miocene of Site 278.

Mesocena oamaruensis Schulz, 1928

(Plate 9, Figures 12, 13, 20)

Remarks: Simple, more or less triangular forms without radial spines and straight or convex sides occur sporadically in the Oligocene and are dominant in a single sample of the Eocene of Site 277.

\section{Mesocena occidentalis Hanna 1931 \\ (Plate 10, Figures 15, 16)}

Remarks: $M$. occidentalis was originally described from the upper Eocene Kreyenhagen Shale in California. It occurs in the Oligocene, and late Eocene of several sites. It was also reported from Oamaru, New Zealand (M. oamaruensis in Mandra and Mandra, 1971).

\section{Mesocena pappii Bachmann 1962 \\ (Plate 10, Figures 4, 9)}

Remarks: M. pappii, with its double radial spines in the corner of the triangle is rare in samples of mid Miocene age at Site 278.

\section{Mesocena? sp. 1 \\ (Plate 8, Figure 5)}

Remarks: At first glance, this large triangular form without radial spines resembles an enormous Mesocena. However, it might well be a ring of a diatom. A single specimen was found in the late Eocene of Site 283.

\section{Mesocena sp. 2}

(Plate 8, Figures 7,8)

Remarks: The specimen illustrated here from the late Eocene of Site 283 might represent an abnormal specimen of $M$. occidentalis which also occurs in the same sample. Three of the four long spines are duplicated while the fourth is in common to the double-skeleton. 
Mesocena sp. 3

(Plate 13, Figures 11, 12)

Remarks: Mesocena sp. 3 is a more or less oval form, tending towards a triangular outline. The three radial spines are short. On Plate 13, Figure 12, the short base of the triangle has broken off and the form then resembles the Late Cretaceous Lyramula. Mesocena sp. 3 is rare in the Miocene of Site 278 .

\section{Genus NAVICULOPSIS Frenguelli 1940 \\ Naviculopsis biapiculata s.l. \\ (Lemmermann) Frenguelli 1940 \\ (Plate 12, Figures 18-22)}

Remarks: The forms assigned here to $N$. biapiculata have a narrow apical bar, typical for this species. The basal body ring, however, is often shorter than the illustrated specimens of $N$. biapiculata in Ling (1972) and Loeblich et al. (1968). On the other hand, these forms have longer radial spines than $N$. iberica Deflandre and their basal body ring is not so square or broad, as in N. quadrata (Ehrenberg) Ling, or N. lata (Deflandre) Frenguelli. N. biapiculata was found at Sites 277 , 278, and 280, from the late Eocene to early Miocene. An abnormal form with an additional lateral bar was found in the late Eocene of Site 277 (Plate 13, Figure 22).

\section{Naviculopsis constricta (Schulz) Stradner 1961}

$$
\text { (Plate 12, Figures 16, 17, 23) }
$$

Remarks: Specimens of $N$. constricta were found in samples of Sites 277,283 , and 281 . They vary in the size of the basal body ring as well as the length of the radial spines. The apical structure is usually wider and flatter than in N. biapiculata, but not as wide as in $N$. foliacea, where it reaches one third of the central opening.

\section{Naviculopsis foliacea Deflandre 1950} (Plate 12, Figure 15)

Remarks: Representatives of this species are rare in some late Eocene samples of Sites 277, 281, and 283. The apical plate is flat and covers about one third of the central opening of the basal body ring.

\section{Naviculopsis lata (Deflandre) Frenguelli 1940 \\ (Plate 17, Figures 7,8)}

Remarks: $N$. lata is rare in the mid Miocene of Site 278. It was originally described from sediments of the same age in Italy.

\section{Naviculopsis cf. N. lata \\ (Deflandre) Frenguelli 1940 \\ (Plate 12, Figures 9-14)}

Remarks: The forms assigned to $N$. cf. $N$. lata are generally not quite as broad as $N$. lata, and their radial spines are longer than in $N$. lata. They are smaller and broader than $N$. biapiculata, and are common in some samples of Sites 277, 278, and 280 (see Plate 12).

\section{Naviculopsis robusta Deflandre 1950}

(Plate 12, Figures 5,6)

Remarks: Some specimens of this short, broad species of Naviculopsis were found in the early Miocene of Site 278. They vary somewhat in shape and size, but correspond very well with the description and illustrations of this species given by Deflandre (1950) for specimens from the Eocene of the USSR.

\section{Naviculopsis trispinosa (Schulz) Glezer 1966 \\ (Plate 12, Figures 1-4, Plate 13, Figures 1-10)}

Remarks: $N$. trispinosa was found to be rare to common in upper Eocene and Oligocene samples of Sites 277, 278, 280, and 283. The apical spine is often broken, stands vertical, or with an angle of about $80^{\circ}$ to the plane of the basal body ring. Forms with a broken apical spine can easily be mistaken for $N$. biapiculata. A large Oligocene specimen with extremely curved spine is shown in Plate 13, Figure 10.

\section{Genus PARADICTYOCHA Frenguelli 1940}

Dumitrica (1973) has recently reviewed the genus Paradictyocha, and discussed the content of its generotype as seen by Frenguelli
(1940). He concludes that $P$. apiculata (Lemmermann) should be regarded as generotype, and the genus includes relatively large species with generally more than six radial horns, with or usually without an apical apparatus. Here, only forms without an apical apparatus, so called mesocenoid forms, are included in Paradictyocha.

\section{Paradictyocha apiculata \\ (Lemmermann) Frenguelli 1940}

(Plate 11, Figures 14, 15)

Remarks: For synonymy and discussion of the species see Dumitrica (1973). Typical specimens of this species were mainly found in the upper Miocene samples from Site 278. The range of this species is, according to Dumitrica (1973), mid and late Miocene. (See also fig. 5-8 and discussion under $P$. dumitricae.)

\section{Paradictyocha cf. P. apiculata \\ (Lemmermann) Frenguelli 1940 \\ (Plate 11, Figures 9, 10,13)}

Remarks: $P$. cf. $P$. apiculata differs from $P$. apiculata by the diameter of the central canal which is much larger in respect to the diameter of the basal ring in $P$. cf. $P$. apiculata. The latter also only occurs in the Pliocene of Site 278, while $P$. apiculata was found in the late Miocene of that site.

\section{Paradictyocha circulus (Ehrenberg) Dumitrica 1973 \\ (Plate 11, Figure 12)}

Remarks: $P$. circulus has only very short radial spines more or less in the plane of the basal ring. It occurs in the Pliocene of Site 278, which agrees with the observations of Dumitrica (1973) who reviewed the species from the southwestern Pacific.

\section{Paradictyocha dumitricae n.sp.}

(Plate 11, Figures 1, 5-8)

Name: to honor D. Paulian Dumitrica, Bukarest, Romania, whose suggestions for the species and genus determinations were largely followed.

Holotype: Plate 11, Figure 7.

Diagnosis: Paradictyocha with a polygonal outline, short radial spines, and no lateral spines.

Description: The outline of $P$. dumitricae is polygonal rather than round, with a short radial spine in each corner. The number of radial spines does not increase with increasing size of the basal ring (see Figures 2,3) and the distance between the radial spines varies somewhat. Specimens with 11-21 spines of equal length have been found.

Remarks: $P$. dumitricae differs from $P$. apiculata by the lack of lateral spines which are also present in $P$. circulus and $P$. cf. $P$. apiculata. The two first named forms also usually have a round outline. $P$. cf. $P$. apiculata, from the same sample, has about twice as many spines as $P$. dumitricae, which supports the suggestion that both species derive from Distephanus polyactis: $P$. cf. $P$. apiculata by disappearance of the apical apparatus, and $P$. dumitricae by the disappearance also of the lateral spines which are still present in $P$. cf. $P$. apiculata. Very few forms which seem to lie in between the two species were found. From the late Miocene (Core 278-14) to the (?)early Pliocene (Core 278-9), the mean size of the diameter remains about the same, while the number of spines increases considerably (from 22-28 to 30-34) from $P$. appiculata to $P$. cf. apiculata. In $P$. dumitricae the number of spines remains about the same, while the diameter increases slightly over the same interval (see Figures 2, 3) Also, $P$. dumitricae takes a larger percentage of the assemblage in relation to $P$. apiculata (resp. $P$. cf. $P$. apiculata) in the younger sample.

Occurrence: P.dumitricae was found from the late Miocene to the Pliocene of Site 278.

\section{Genus SEPTAMESOCENA Bachmann 1970}

\section{Septamesocena apiculata (Schulz) Bachmann 1970}

(Plate 10, Figures 2, 3, 5-8, 10)

Remarks: Dumitrica (1973) has recently discussed the generic differences between Mesocena and Septamesocena which he sees in the oblique orientation of the radial spines toward the plane of the basal 


\section{K. PERCH-NIELSEN}

\section{Paradictyocha dumitricae 278-9-1}
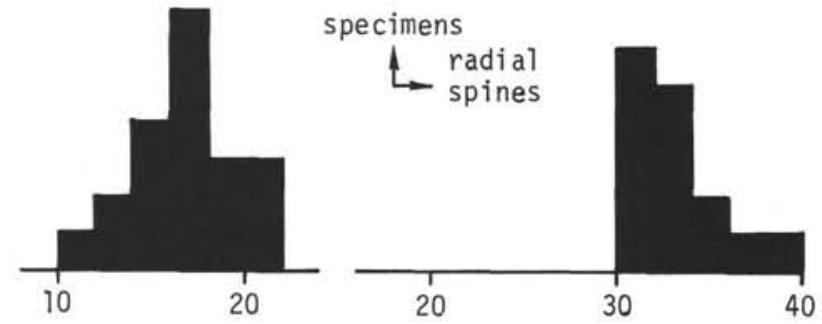

$278-14(C C)$
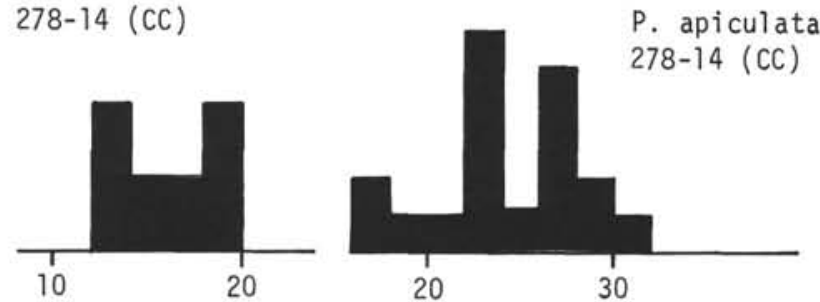

Figure 2. Frequency distribution of number of radial spines in Paradictyocha dumitricae, $\mathrm{P}$. apiculata and $\mathrm{P}$. cf. P. apiculata in 278-9-1, and 278-14, CC.

ring, while the presence or absence of septae is considered of less importance. In the forms of this species found to be rare to abundant in the Pliocene, Miocene, Oligocene, and late Eocene, septae are present or absent, but the radial spines are oriented obliquely towards the plane of the basal ring. The outline and size of the basically triangular species vary considerably and the radial spines are short.

\section{Septamesocena cf. S. quadrangula \\ (Schulz) n. comb.}

(Plate 10, Figures 17, 18)

Mesocena oamaruensis Schulz var. quadrangula Schulz 1928, p. 240, fig. 13 , non-fig. 12

Remarks: Schulz (1928) also illustrated an unregularly quadrangular form with small "internal radial spines" under the name of $M$. oamaruensis quadrangula. The other specimen illustrated has very long spines, and such forms are here referred to $M$. occidentalis Hanna. $S$. cf. $S$. quadrangula has very small to no radial

$$
\begin{array}{ll}
\text { P. dumitricae } & \text { P. cf. apiculata } \\
278-9-1 & 278-9-1
\end{array}
$$
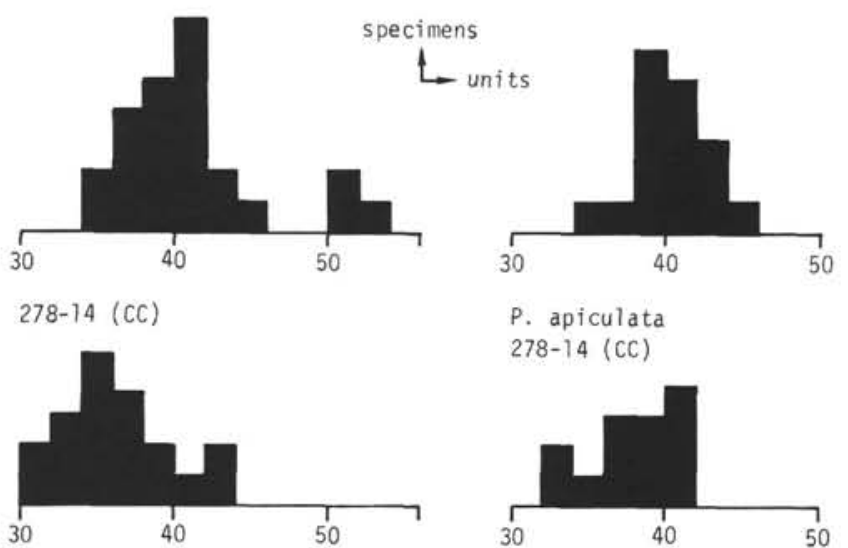

Figure 3. Frequency distribution of diameter (in units of $\sim 2.5$ of Paradictyocha dumitricae. P. $c f$. apiculata, and $\mathrm{P}$. apiculata in 278-9-1, and 278-14, CC. spines and sometimes septae. The outline is irregular with four corners, and the size varies considerably. This form is very rare in the late Eocene of Site 277, and in the early Miocene of Site 278.

\section{Septamesocena sp. \\ (Plate 10, Figure 11)}

Remarks: A single specimen with a rounded outline and three radial spines, which are oriented obliquely to the plane of the basal ring, was found in the Oligocene of Site 280.

\section{Genus VALLACERTA Hanna 1928b \\ Vallacerta hortonii Hanna, 1928b \\ (Plate 14, Figures 2, 5, 7, 8)}

Remarks: Typical specimens of $V$. hortonii are not rare in the Upper Cretaceous samples of Site 275. A single specimen lacking the central plate was also found (Plate 14, Figure 8).

\section{Vallacerta sidera (Schulz) \\ Ling et al. 1973 \\ (Plate 14, Figures 3,6)}

Remarks: Ling et al. (1973) consider that the superficial structure of $V$. siderea differs from that of $V$. hortonii, and that the two species are not synonymous, as they were regarded by previous authors. Irrespective of whether there is such a difference in superficial structure, there is a visible difference in the LM between $V$. hortonii and what Ling et al. (1973) consider as $V$. siderea. The difference consists in the fact that in the latter, the inner borders of the plate advance much along the spines, forming an acute angle, and the outer borders are concave, rendering the boundary between the plate and the spines difficult to be traced. These peculiarities are more or less obvious in the pentagonal forms illustrated by Schulz. There is also a third difference, at least in our material, consisting in the absence of the sustaining spines in $V$. siderea and their presence in $V$. hortonii.

\section{Vallacerta ef. V. tumidula Glezer 1959 \\ (Plate 14, Figures 1, 4, 9, 10)}

Remarks: The illustrations given by Glezer, $V$. cf. $V$. tumidula show a round central plate that is not so sharply limited as in the specimens illustrated here. Also V. tumidula has decorations visible in the LM in the central area, while it seems smooth in our specimens, and looks almost like an opening (see Plate 14). It can be seen on the SEM picture that the round central plate is surrounded by a shallow ditch (Chapter 24, this volume). Like $V$. tumidula, our form occurs only in the Late Cretaceous at Site 275, where it is not rare.

\section{ACKNOWLEDGMENTS}

I would like to thank Dr. P. Dumitrica for his advice in determining many of the silicoflagellates and for reading critically an early version of the manuscript. I am also grateful to the Laboratoire de Micropaléontologie, Ecole pratique des Hautes Etudes in Paris for giving me the opportunity to study their type collection which includes the holotypes of some species treated here. My participation in Leg 29 was made possible by a grant from the Danish National Science Foundation.

\section{REFERENCES ${ }^{2}$}

Bachmann, A., 1962. Eine neue Mesocena-Art (Silicoflagellidae) aus dem kalifornischen Eozän: Verhandl. Geol. B.-A. p. 378-383.

1970. Silicoflagellaten aus dem oberösterreichischen Egerien (Oberoligozän): Verhandl. Geol. B.-A. 2, p. $275-305$.

${ }^{2}$ References prior to 1900 are not mentioned in this list, but are included in Loeblich et al. (1968). 
Bukry, D., 1973. Coccolith and silicoflagellate stratigraphy, Deep Sea Drilling Project Leg 18, eastern North Pacific. In Kulm, L. D., von Huene, R., et al., Initial Reports of the Deep Sea Drilling Project, Volume 28: Washington (U.S. Government Printing Office), p. 817-831.

Bukry, D. and Foster, J. H., 1973. Silicoflagellate and diatom stratigraphy, Leg 16, Deep Sea Drilling Project. In van Andel, T. H., Heath, G. R., et al., Initial Reports of the Deep Sea Drilling Project, Volume 16: Washington (U.S. Government Printing Office), p. 815-871.

, in press. Silicoflagellate zonation of Upper Cretaceous to lower Miocene deep-sea sediment: U.S. Geol. Surv. J. Res.

Deflandre, G., 1932a. Les silicoflagellees des terres fossiles a diatomées: Soc. Micropaleontol., France Bull., v. 1, p. 1020.

1932b. Sur la Systématique des Silicoflagellées: Soc. Bot. France Bull., v. 79, p. 494-506.

1940. L'origine phylogénétique des Lyramula et l'évolution des silicoflagellidées: C. R. Acad. Sci. Paris, v. 211 , p. $508-510$.

1950. Contribution à l'ètude des silicoflagellidés actuels et fossiles: Microscopie, v. 2, p. 72-108, 117-142, 191- 210.

Dumitrica, P., 1973. Paleocene, late Oligocene, and postOligocene silicoflagellates in southwestern Pacific sediments cored in Leg 21 of the DSDP: In Burns, R. E., Andrews, J. E., et al., Initial Reports of the Deep Sea Drilling Project, v. 21: Washington (U.S. Government Printing Office), p. 837-883.

Frenguelli, J., 1940. Consideraciones sobre los sílicoflagelados fósiles: Rev. Mus. La Plata 2/2, Paleontol. 7, p. $37-112$.

Gemeinhardt, K., 1934. Die Silicoflagellaten des Südatlantischen Ozeans: Ergebnisse der deutschen AtlantikExpedition "Meteor" 1925-1927, 12/1/3, p. 274-312.

Glezer, Z. I., 1959. Nekotorye novye dannye o semeystve Vallacertaceae Deflandre (Silicoflagellatae): Vses. Nauchno-Issledov. Geol. Inst. (VSEGEI), Inform. Sbornik 10, Stratigr. i Paleont., p. 103-113.

1964. Novye kremnevye zhgutikovye vodorosli Paleogena SSSR, Silicoflagellatae: fossiles nova URSS: Akad. Nauk SSSR, Novsti sistematiki nizshikh rasteniy, otdel. ottisk, p. 46-58.

1966. Kremnevye zhgutikovye vodorosli (Silicoflagellaty). Silicoflagellatophycaeae: Flora Sporovykh Rasteniy SSR, Flora Platarum Cryptogammarum URSS 7 Akad. Nauk SSSR, Botanicheskiy Inst. V. L. Komarova, Moscow, Leningrad, p. 1-330.

Hanna, G. D., 1928a. The Monterey Shale of California at its type locality with a summary of its fauna and flora: Am. Assoc. Petrol. Geol. Bull., v. 12, p. 969-983.

1928b. Silicoflagellata from the Cretaceous of California: J. Paleontol., v. 1, p. 259-263.

1931. Diatoms and silicoflagellates of the Kreyenhagen Shale. In Mining in California: p. 197-201.

Hays, J. D., Saito, T., Opdyke, N. D., and Burckle, L. H., 1969. Pliocene-Pleistocene sediments of the equatorial Pacific: Their paleomagnetic, biostratigraphic and climatic record: Geol. Soc. Am. Bull., v. 80, p. 1481-1513.
Lemmermann, E., 1901. Silicoflagellatae: Deutsche Bot. Ges. Ber., v. 19 , p. $247-271$.

Ling, H. Y., 1970. Silicoflagellates from central north Pacific core sediments: Am. Paleontol. Bull., v. 58, p. 85-129.

1971. Silicoflagellates and ebridians from the Shinzan diatomaceous mudstone member of the Onnagawa Formation (Miocene), northeast Japan: In Plankt. Conf. Second, Rome, 1970, Proc., Farinacii, A. (Ed.) Tecnoscienza, v. 2, p. 689-703.

1972. Upper Cretaceous and Cenozoic silicoflagellates and ebridians: Am. Paleontol. Bull., v. 62, p. 133-229.

1973. Silicoflagellates and ebridians from Leg 19. In Creager, J. S., Scholl, D. W., et al., Initial Reports of the Deep Sea Drilling Project, Volume 19: Washington (U.S. Government Printing Office), p. 751-775.

Ling, H. Y., McPherson, L. M., and Clark, D. L., 1973. Late Cretaceous (Maestrichtian?) Silicoflagellates from the Alpha Cordillera of the Arctic Ocean: Science, v. 180, p. $1360,1361$.

Loeblich, A. R., III, Loeblich, L. A., Tappan, H., and Loeblich, A. R., Jr., 1968. Annotated index of fossil and Recent silicoflagellates and ebridians with descriptions and illustrations of validly proposed taxa: Geol. Soc. Am. Mem. 106, p. 1-319.

Mandra, Y. T., 1968. Silicoflagellates from the Cretaceous, Eocene, and Miocene of California, USA: California Acad. Sci. Proc., p. 231-277.

1969a. A new genus of Silicoflagellata from an Eocene South Atlantic Deep-Sea core: California Acad. Sci., Occ. Paper 77, p. 1-7.

1969b. Silicoflagellates: a new tool for the study of antarctic Tertiary climates. Antarctic J. U.S., v. 4, p. 172174.

Mandra, Y. T. and Mandra, H., 1971. Upper Eocene silicoflagellates from New Zealand: Antarctic J. U.S., v. 6, p. 177-178

Mandra, Y. T., Brigger, A. L., and Mandra, H., 1973. Preliminary report on a study of fossil silicoflagellates from Oamaru, New Zealand: California Acad. Sci., Occ. paper 107 , p. $1-11$.

Martini, E., 1971a. Neogene silicoflagellates from the equatorial Pacific. In Winterer, E. L., Riedel, W. R., et al., Initial Reports of the Deep Sea Drilling Project, Volume 7: Washington (U.S. Government Printing Office), p. 16951708.

1971b. Standard Tertiary and Quaternary calcareous nannoplankton zonation. In Plankt. Conf. Second, Rome, 1970, Farinacci, A. (Ed.) Tecnoscienza, v. 2, p. 739785.

1972. Silicoflagellate zones in the late Oligocene and early Miocene of Europe: Senckenb. Lethaia, v. 53, p. 119122.

Schulz, P., 1928. Beiträge zur Kenntnis fossiler und rezenter Silicoflagellaten: Bott. Arch., v. 21, p. 225-292.

Stradner, H., 1961. Über fossile Silicoflagelliden und die Möglichkeit ihrer Verwendung in der Erdölstratigraphie: Erdöl Kohle, v. 14, p. 87-92.

Tsumura, K., 1963. A systematic study of silicoflagellatae: Yokohama Mun. Univ. J. C-45, v. 146, p. 1-84. 


\section{PLATE 1}

Silicoflagellates

(Magnification $\sim \times 800$ )

Figures 1-5 Cannopilus depressus (Ehrenberg). Sample 278-20$6,130 \mathrm{~cm}$.

Figure 6 Cannopilus major (Frenguelli). Sample 280A-3, CC.

Figure 7 Distephanus speculum (Ehrenberg). Sample 27820-6, $130 \mathrm{~cm}$.

Figures 8,9 Cannopilus quintus Bukry and Foster.

8. Sample $278-20-6,130 \mathrm{~cm}$.

9. Sample 280A-6, CC.

Figures 10-12 Cannopilus hemisphaericus (Ehrenberg)

10. Sample 278-29, CC.

11 , 12. Sample 278-23-3, $110 \mathrm{~cm}$.

Figure 13 Distephanus octonarius (Ehrenberg). Sample 278-3, CC. 
PLATE 1
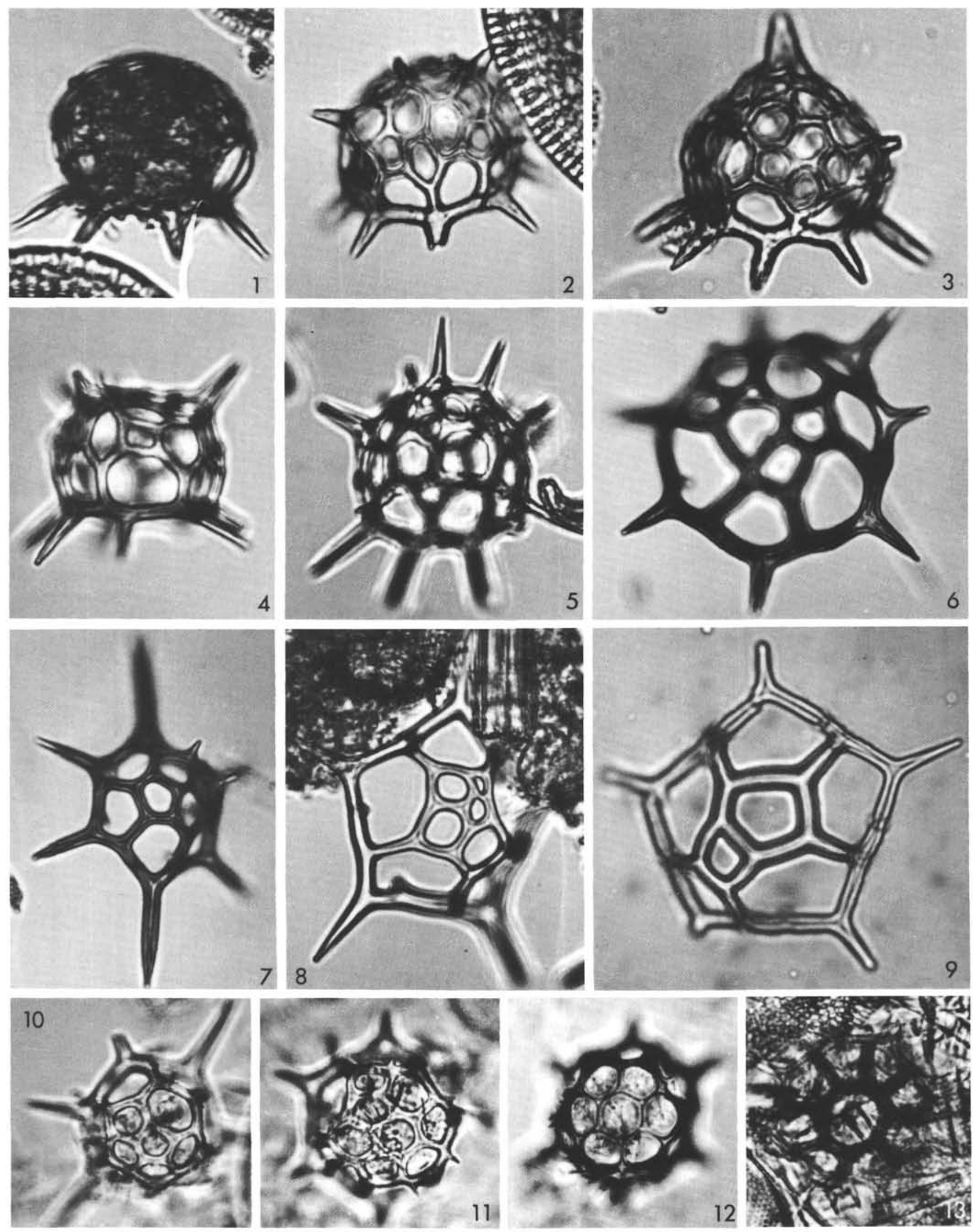


\section{PLATE 2}

Late Cretaceous Silicoflagellates

(Magnification $\sim \times 500$ )

Figures 1-6, 8 Corbisema geometrica Hanna

$1,4,6$. Sample $275-2-3,50 \mathrm{~cm}$.

$2,3,5$. Sample $275-1-4,50 \mathrm{~cm}$.

8. Sample 275-1, CC.

Figures 7, 10, Corbisema lateradiata (Schulz)

$11,17,18 \quad 7,10,11$. Sample 275-2-3, $50 \mathrm{~cm}$.

17,18 . Sample $275-1-1,130 \mathrm{~cm}$.

Figures 9, 13 Dictyocha quadralta Hanna. Pentagonal and 14 hexagonal forms.

9, 14. Sample $275-2-3,50 \mathrm{~cm}$.

13. Sample $275-1-4,50 \mathrm{~cm}$.

Figure 12 Corbisema sp. 1. Specimen with open basal ring. Sample 275-1-3, $50 \mathrm{~cm}$.

Figures 15, 16, Corbisema apiculata (Lemmermann)

19

15. Sample 275-1, CC.

16. Sample 275-2-3, 50 .

19. Sample 275-1-1, 130. 
PLATE 2
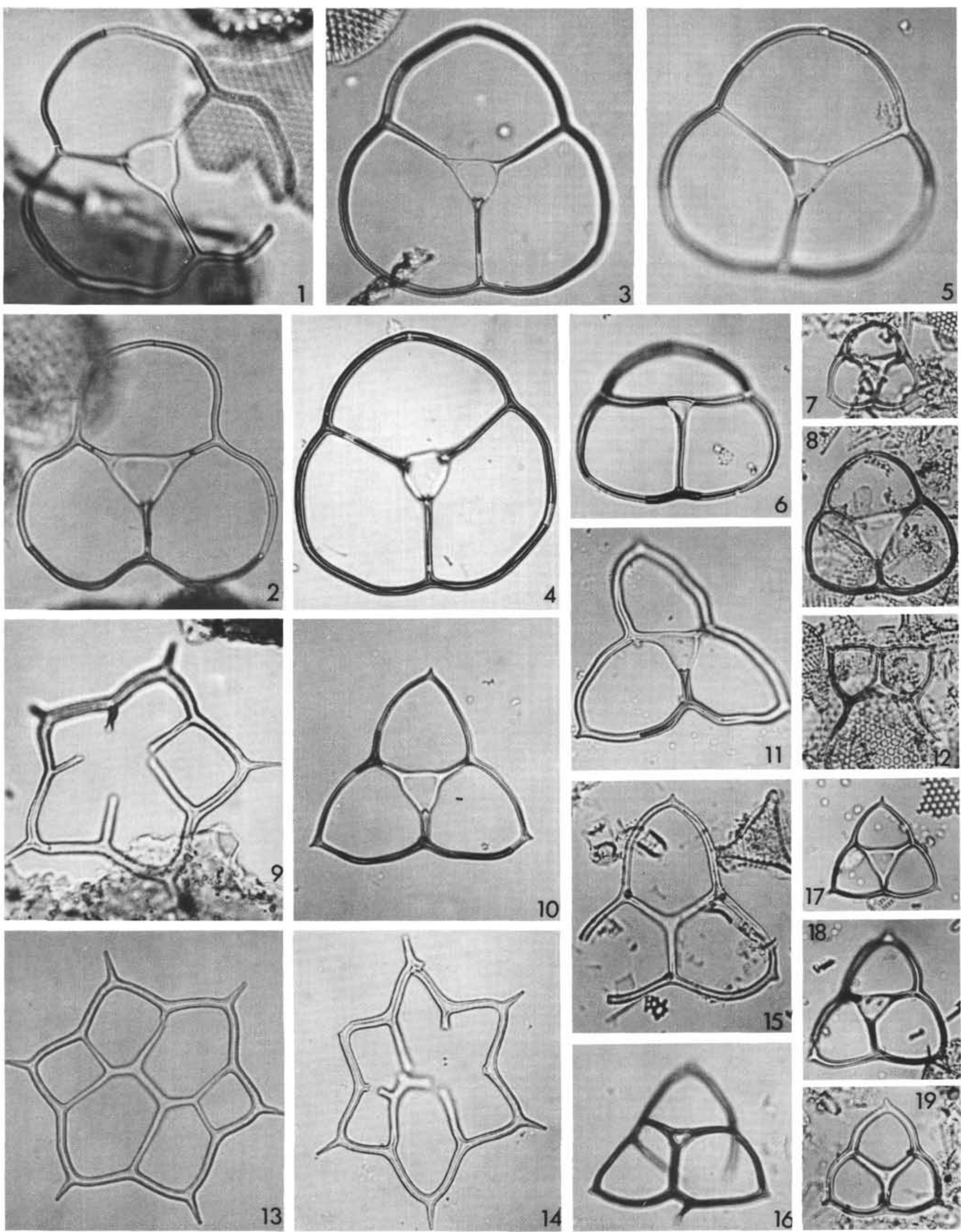


\section{PLATE 3}

Silicoflagellates

(Magnification $\sim \times 800$ )

Figure 1 Corbisema sp. 2. Sample 280A-1-2, $120 \mathrm{~cm}$.

Figure 2-4, Corbisema hastata (Lemmermann) 8,21

2. Sample 283-5-2, $117 \mathrm{~cm}$.

3. Sample 283-3-1 (?).

4. Sample $280 \mathrm{~A}-1-2,120 \mathrm{~cm}$.

8. Sample $277-21-2,110 \mathrm{~cm}$.

21. Sample $280 \mathrm{~A}-7-3,110 \mathrm{~cm}$.

Figures 5, 6 Corbisema media (Glezer)

5. Sample 283-5-2, $117 \mathrm{~cm}$.

6. Sample $283-4$, CC.

Figures 7,12 Corbisema minor (Schulz)

7. Sample 283-5-2, $117 \mathrm{~cm}$.

12. Sample $277-17-4,110 \mathrm{~cm}$.

Figure 9 Corbisema bimucronata Deflandre. Sample 283-5$2,117 \mathrm{~cm}$.

Figure 10 Corbisema flexuosa (Stradner). Sample 283-5-2, $117 \mathrm{~cm}$.

Figures 11, 15, Corbisema triacantha (Ehrenberg)

16 11. Sample $277-17-4,110 \mathrm{~cm}$.

15. Sample 278A-2, CC.

16. Sample $278-29, \mathrm{CC}$.

Figures 13, 14 Corbisema hexacantha (Schulz) Deflandre

13. Sample 277-23-2, $10 \mathrm{~cm}$.

14. Sample $281-16$, CC.

Figures 17, 22 Corbisema archangelskiana (Schulz)

17. Sample $277-5-4,110 \mathrm{~cm}$.

22. Sample 278-31, CC.

Figure $18 \quad$ Corbisema cf. C. lamellifera hastata (Glezer) Sample 277-21-2, $110 \mathrm{~cm}$.

Figures 19, 20, Corbisema apiculata (Lemmermann)

24

19. Sample 280A-1, CC.

20. Sample 283-2, CC.

24. Sample $277-23-2,110 \mathrm{~cm}$.

Figure 23 Corbisema spinosa Deflandre. Sample 278-32-1, 99 $\mathrm{cm}$. 
PLATE 3
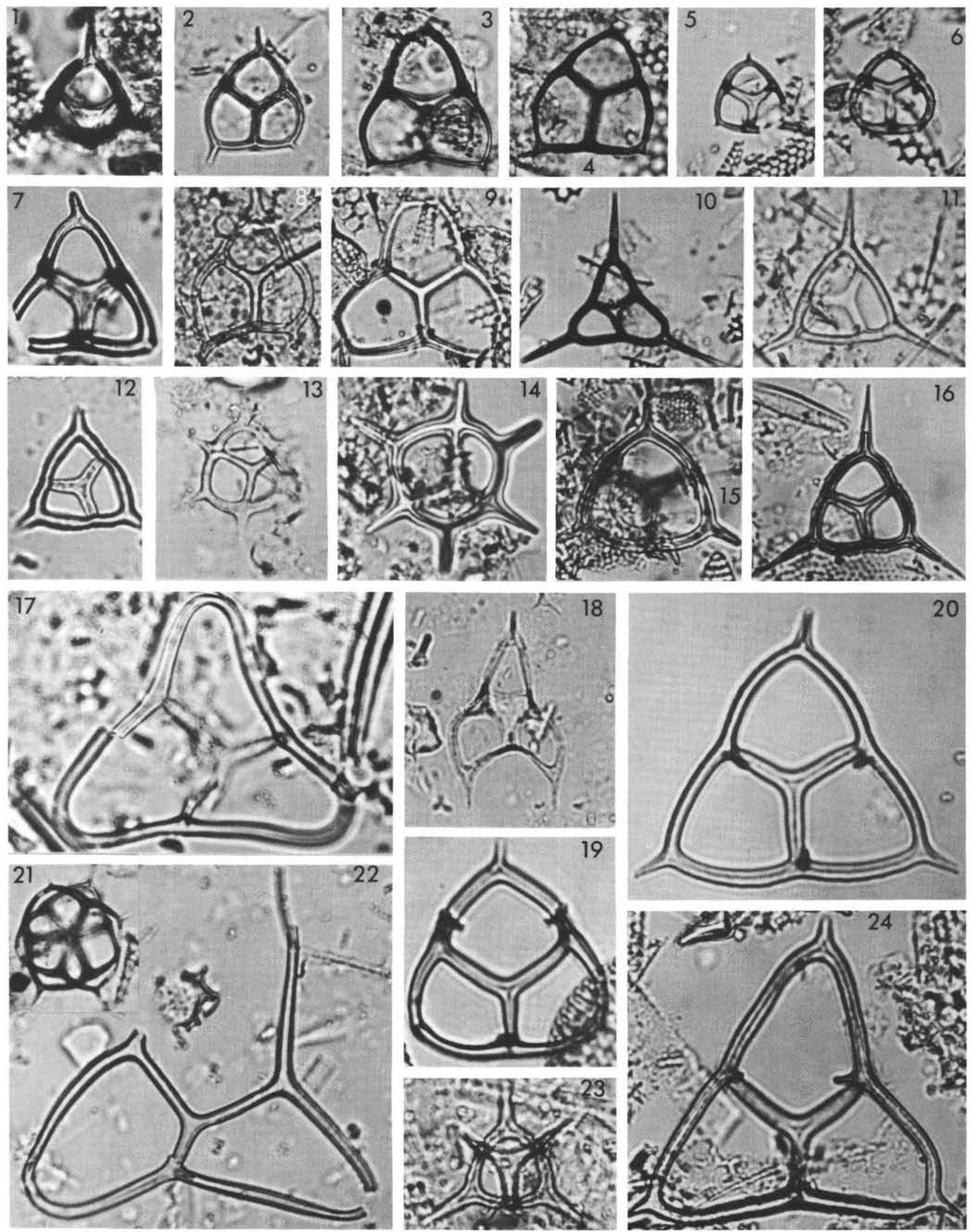
PLATE 4

Silicoflagellates

(Magnification $\sim \times 800$ )

Figures 1, 6 Dictyocha cf. D. carentis Glezer

1. Sample 283-5-2, $117 \mathrm{~cm}$.

6. Sample $277-9-4,110 \mathrm{~cm}$.

Figures 2, 3 Corbisema spinosa Deflandre. Sample 278$33, \mathrm{CC}$; oblique view in high and low focus.

Figures 4, 5 Dictyocha medusa Haeckel

4. Sample 278-9-1, $110 \mathrm{~cm}$.

5. Sample 280A-2, CC.

Figure 7 Dictyocha $\mathrm{cf}$. D. carentis Glezer. Sample 278-32-1, $99 \mathrm{~cm}$; abnormal form.

Figure 8 Dictyocha sp. 1. Sample 278-10-5, $110 \mathrm{~cm}$.

Figures 9, 10, Dictyocha aspera Lemmermann

159 9, 10. Sample 278-10-1, $110 \mathrm{~cm}$.

15. Sample 278-19, CC.

Figures 11, 12 Dictyocha sp. 2

11. Sample $277-23-2,110 \mathrm{~cm}$.

12. Sample 278-11, CC.

Figure 13 Dictyocha mutabilis Deflandre. Sample 278-10-1, $110 \mathrm{~cm}$.

Figures 14, 17 Dictyocha frenguellii Deflandre. Sample 283-5-2, $117 \mathrm{~cm}$.

Figure $16 \quad$ Dictyocha sp. 3. Sample 278-30, CC. 
PLATE 4
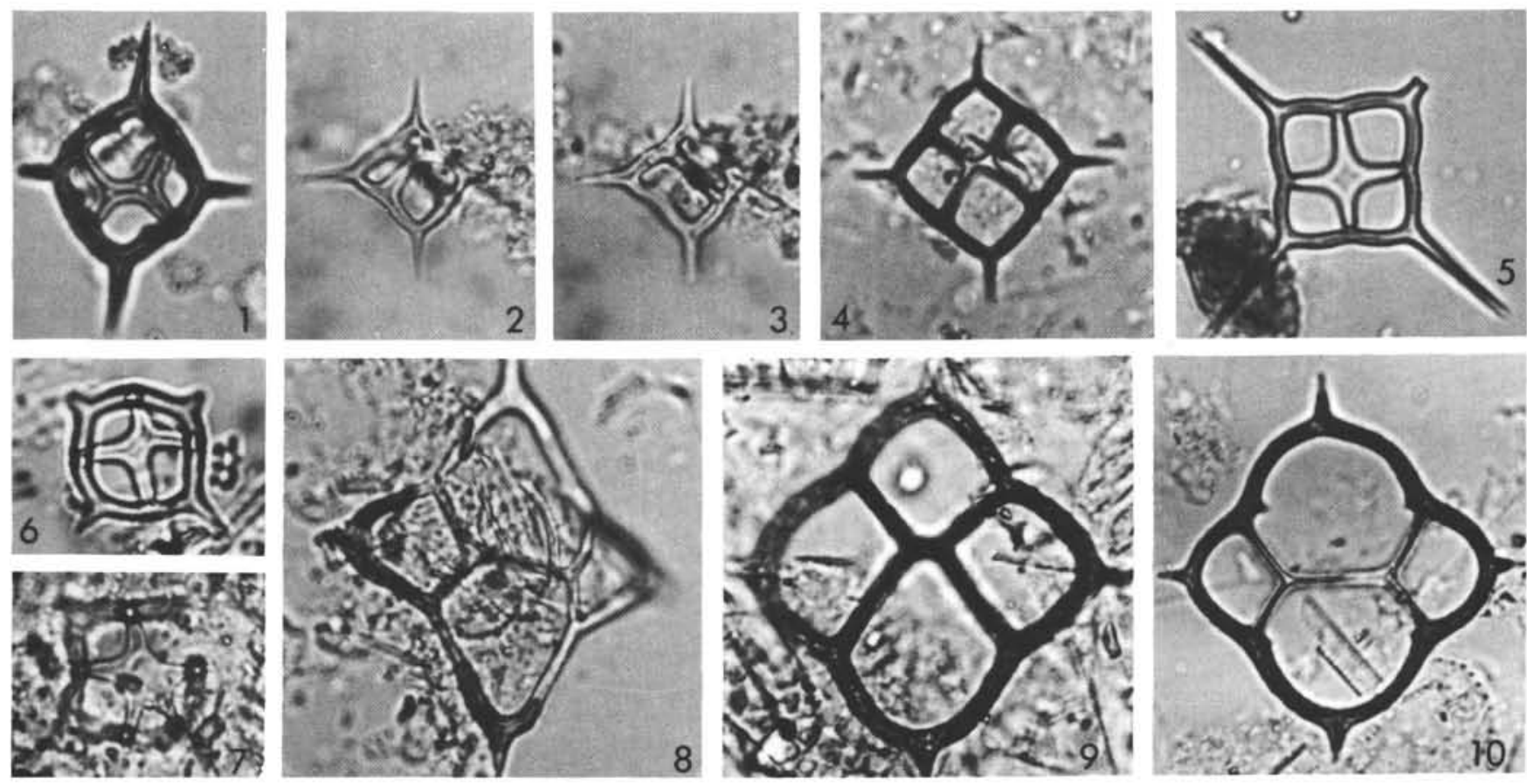
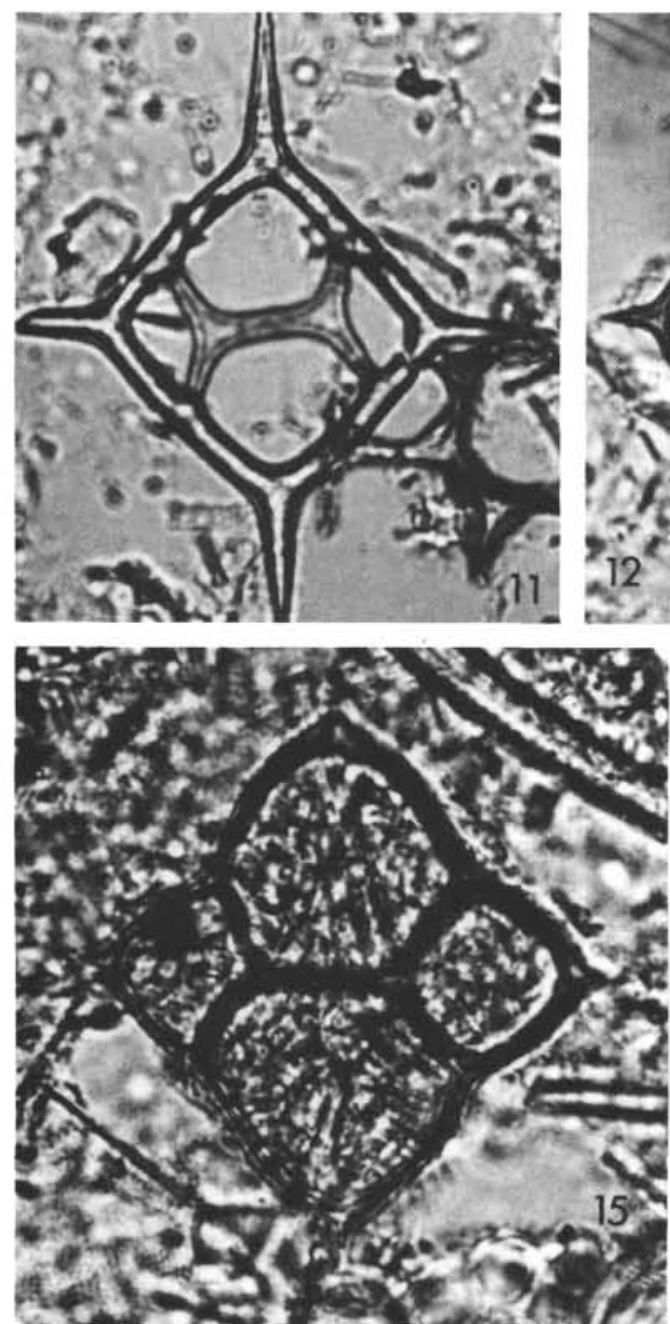
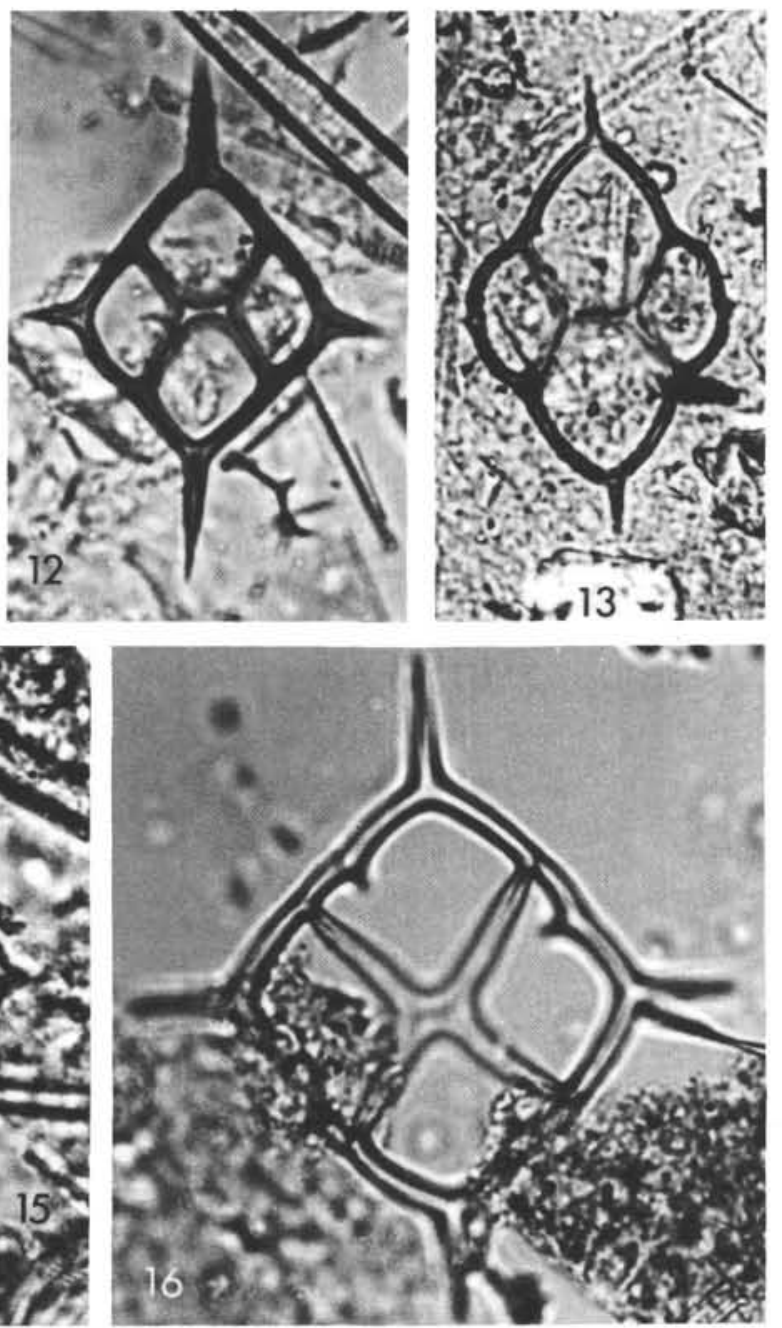

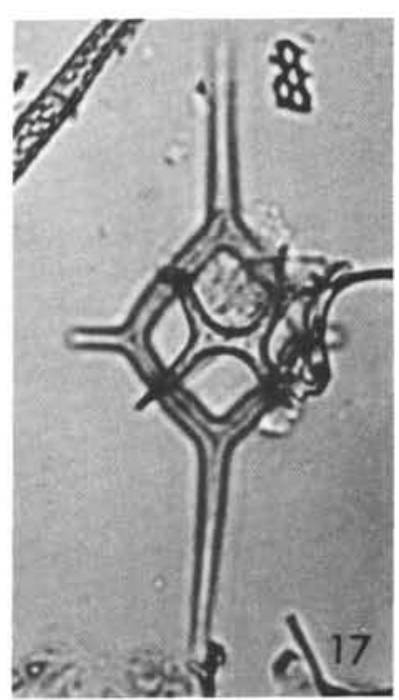




\section{PLATE 5}

Silicoflagellates

(Magnification $\sim \times 800$ )

Figure 1 Dictyocha frenguellii Deflandre. Sample 283-5-2, $117 \mathrm{~cm}$.

Figures 2, 6 Dictyocha cf. D. messanensis Haeckel. Sample $278-10-1,110 \mathrm{~cm}$.

Figures 3, 4 Dictyocha aculeata Lemmermann. Sample 281-1, CC.

Figure 5 Dictyocha fibula Ehrenberg. Sample 28114, CC.

Figures 7, $8 \quad$ Dictyocha cf. D. frenguellii Deflandre.

7. Sample 278-31, CC.

8. Sample 278-32-1, $99 \mathrm{~cm}$.

Figures 9, 10, Dictyocha $\mathrm{cf}$. D. perlaevis Frenguelli.

16, 179,10 . Sample 278-32-1, $99 \mathrm{~cm}$.

16 , 17. Sample $278-10-1,110 \mathrm{~cm}$.

Figure 11 Dictyocha pentagona (Schulz). Sample 277$8-4,110 \mathrm{~cm}$.

Figure 12 Dictyocha pentagonalis (Aurivillius). Sample $278-1-3,118 \mathrm{~cm}$.

Figures 13, 14 Dictyocha messanensis Haeckel. Sample 281-1, CC.

Figure 15 Dictyocha pseudofibula (Schulz). Sample 278-2, CC.

Figure 18 Dictyocha sp. 4. Sample 283-5-2, $117 \mathrm{~cm}$. Fibuloid form of Distephanus crux? 
PLATE 5
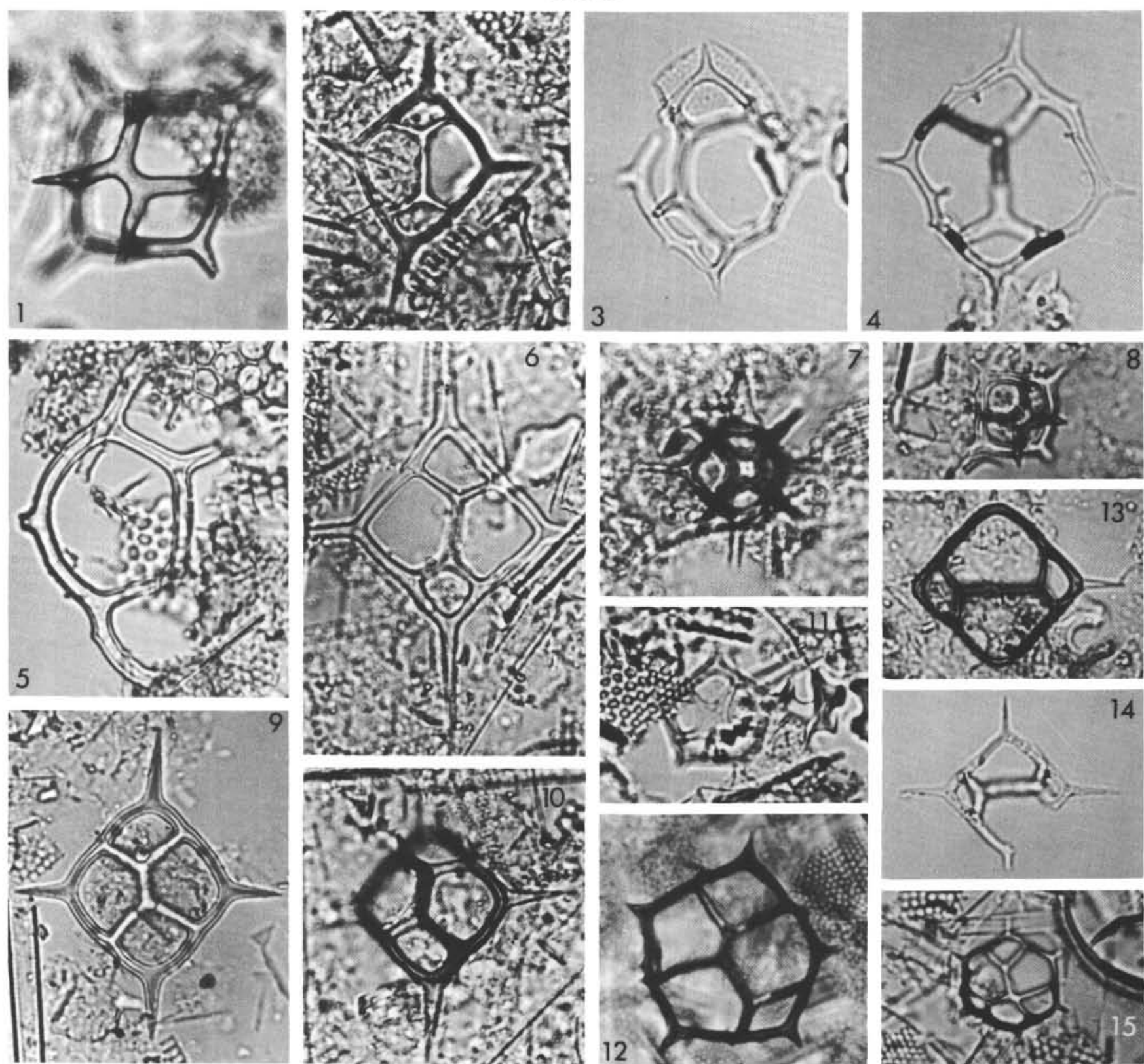
20,
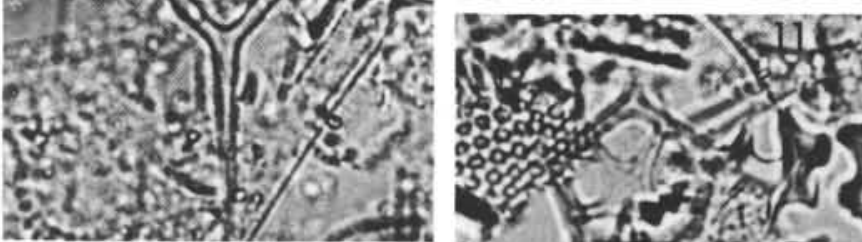

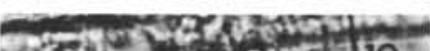
istis a

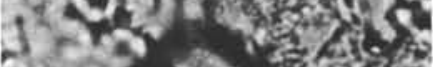
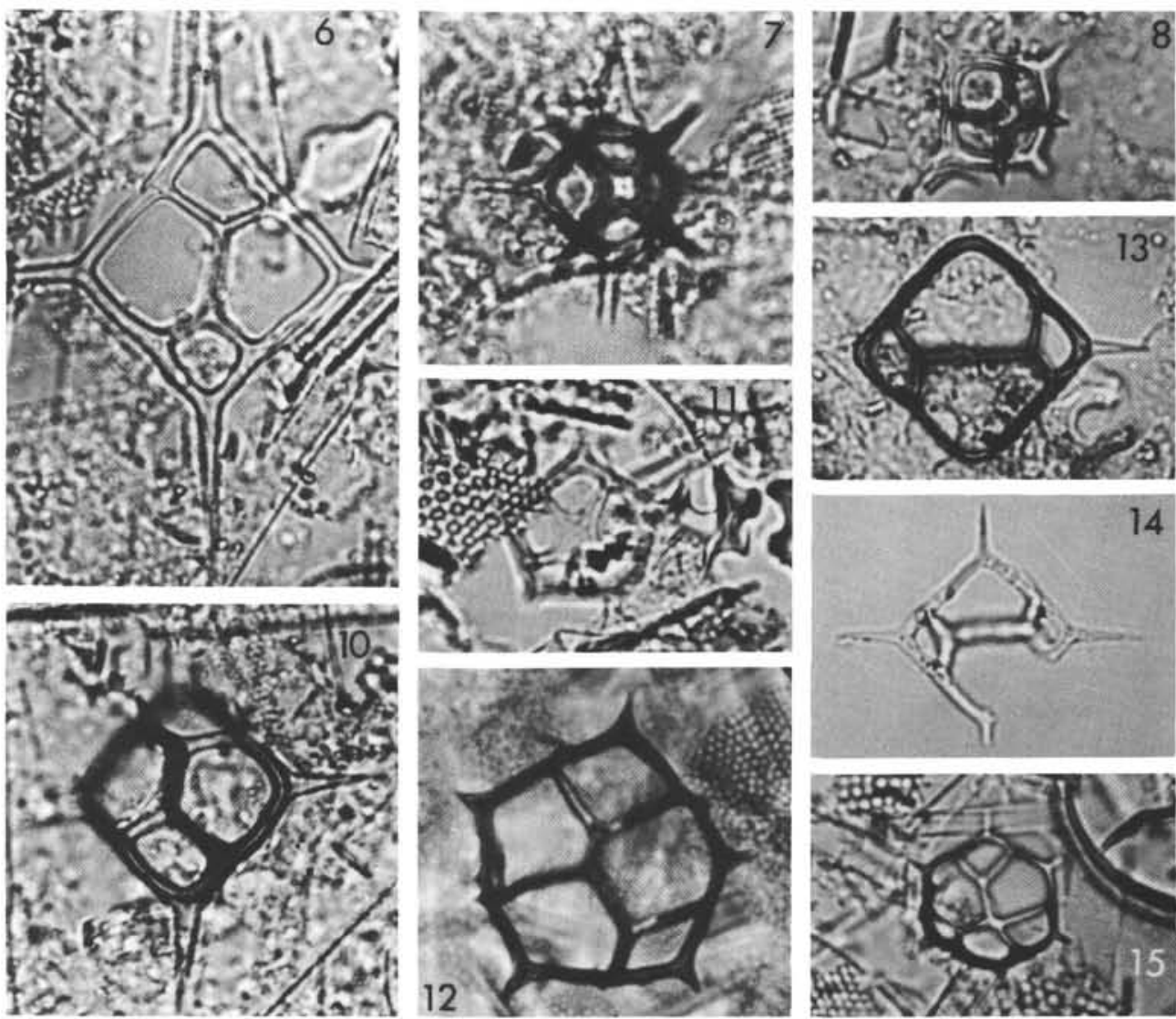

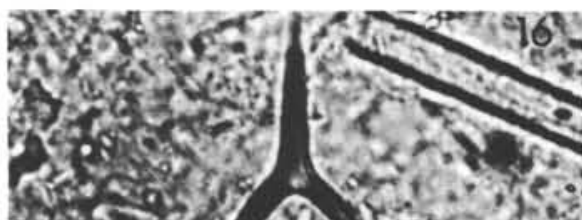
of.

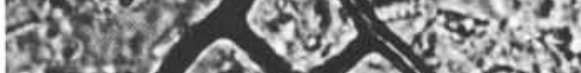

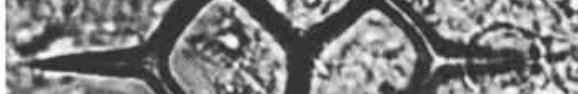

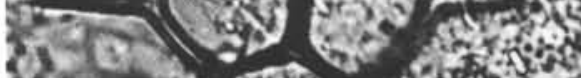

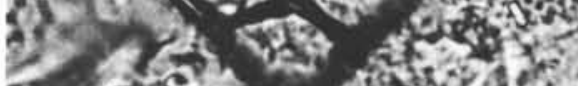

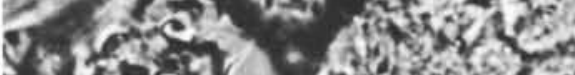

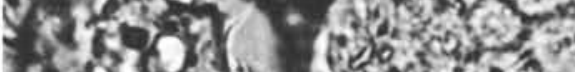

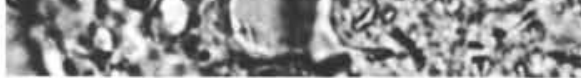
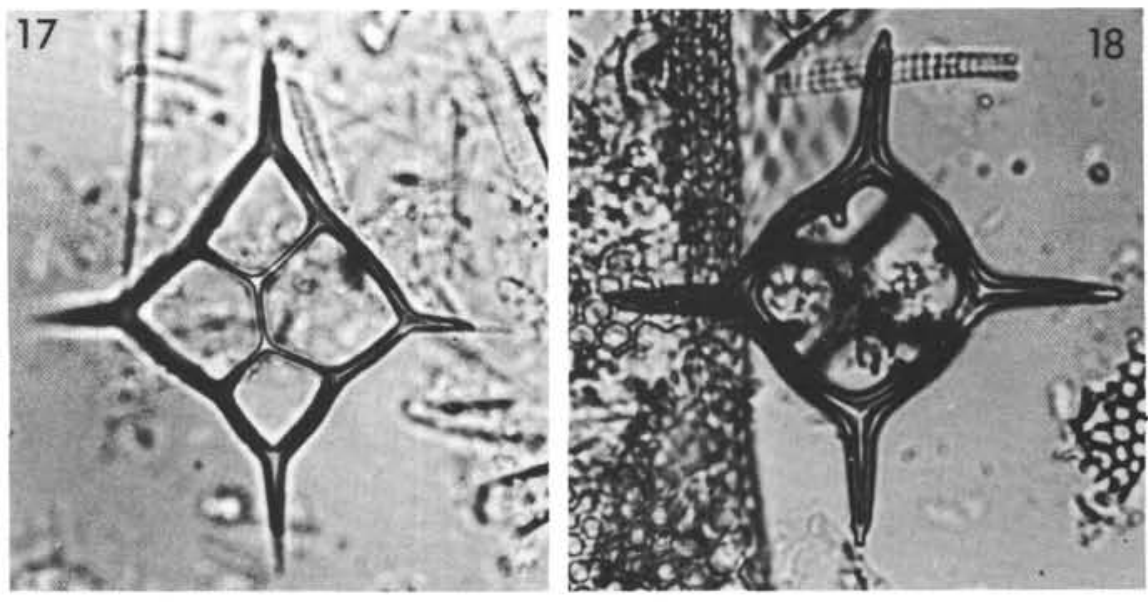
PLATE 6

Silicoflagellates

(Magnification $\sim \times 600$ )

Figures 1, 4, 7 Distephanus crux (Ehrenberg). Abnormal forms.

1. Sample $280 \mathrm{~A}-5, \mathrm{CC}$.

4, 7. Sample $280 \mathrm{~A}-6, \mathrm{CC}$.

Figures 2, 3, 5 Distephanus crux (Ehrenberg). Large forms.

2, 5. Sample 280A-6, CC.

3. Sample $280 \mathrm{~A}-5$, CC.

Figure 6 Distephanus longispinus (Schulz). Sample 278-31, CC.

Figures 8, 9 Distephanus quinquangellus Bukry and Foster. Sample 278-20-6, $130 \mathrm{~cm}$.

Figures 10, 11 Distephanus boliviensis (Frenguelli). Sample 280A-6, CC.

Figures 12, 13 Distephanus speculum s.l. (Ehrenberg).

12. Sample 278-31-2, $110 \mathrm{~cm}$.

13. Sample $278-20-6,130 \mathrm{~cm}$. 
PLATE 6
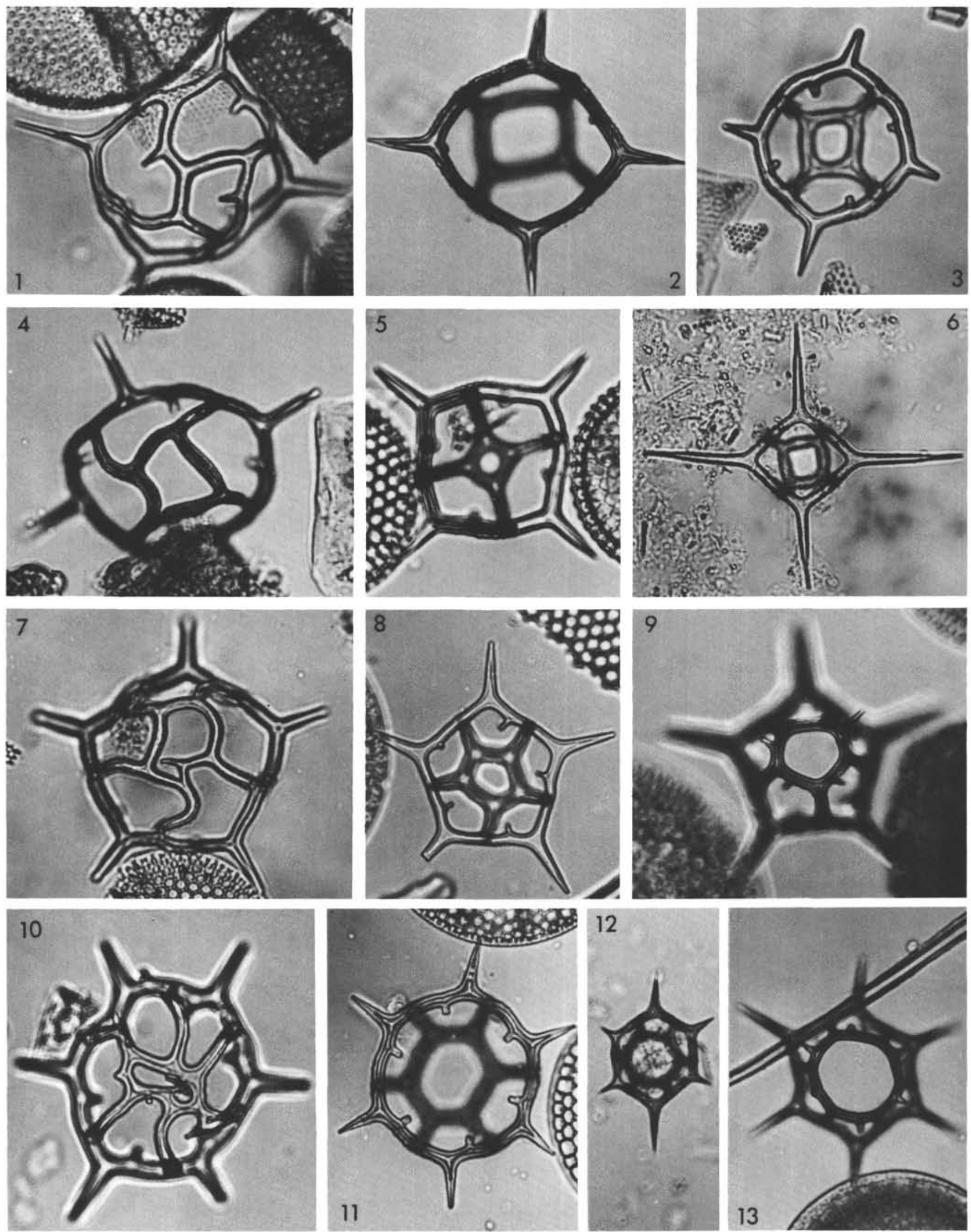
PLATE 7

Silicoflagellates

(Magnification $\sim \times 800$ )

Figures 1-5, Distephanus crux s.l. (Ehrenberg).

7-10, 13 1, 2, 5. Sample 277-12-4, $110 \mathrm{~cm}$.

$3,7,13$. Sample $283-5-2,117 \mathrm{~cm}$.

4. Sample 278-1-3, $118 \mathrm{~cm}$.

8, 9. Sample $278-29$, CC.

10. Sample $278-31-2,110 \mathrm{~cm}$.

Figure 6 Distephanus macilentus (Deflandre). Sample 277-21-2, $110 \mathrm{~cm}$.

Figures 11, 14, Distephanus quinquangellus Bukry and 15 Foster.

11. Sample 278-20-6, $130 \mathrm{~cm}$; abnormal form.

14. Sample 278-11, CC.

15. Sample 278A-1, CC.

Figure 12 Distephanus polyactis (Ehrenberg). Sample $278-1-11,110 \mathrm{~cm}$.

Figures 16-18, Distephanus speculum s.l. (Ehrenberg).

23

16. Sample 278A-2, CC.

17. Sample 278-1, CC.

18. Sample 278-9-1, $110 \mathrm{~cm}$.

23. Sample 278-28, CC.

Figures 19, 20 Distephanus octogonus (Ehrenberg).

19. Sample 278-3, CC.

20. Sample 278-6, CC.

Figures 21, 22 Distephanus septenarius (Ehrenberg).

21. Sample 278-1-3, $118 \mathrm{~cm}$.

22. Sample 280A-2, CC. 
PLATE 7
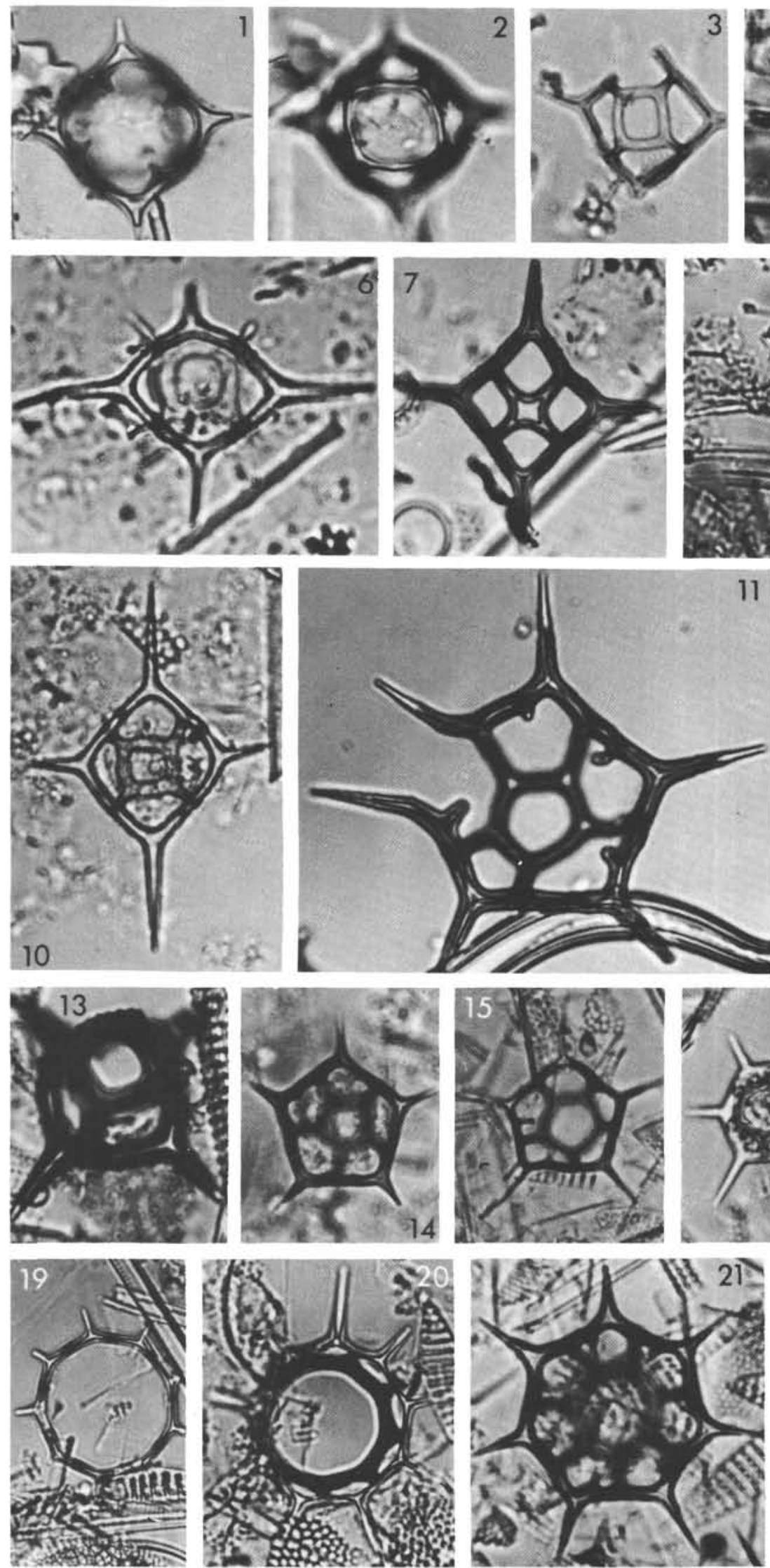

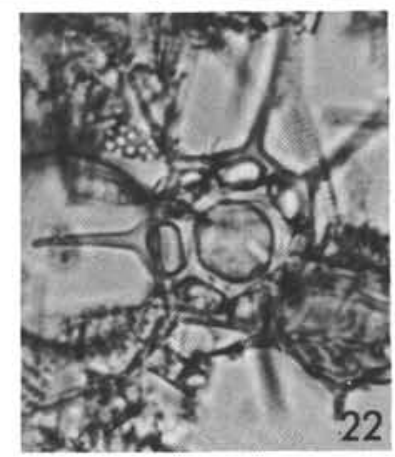

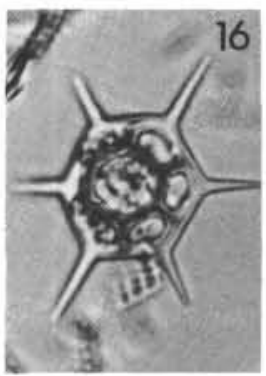
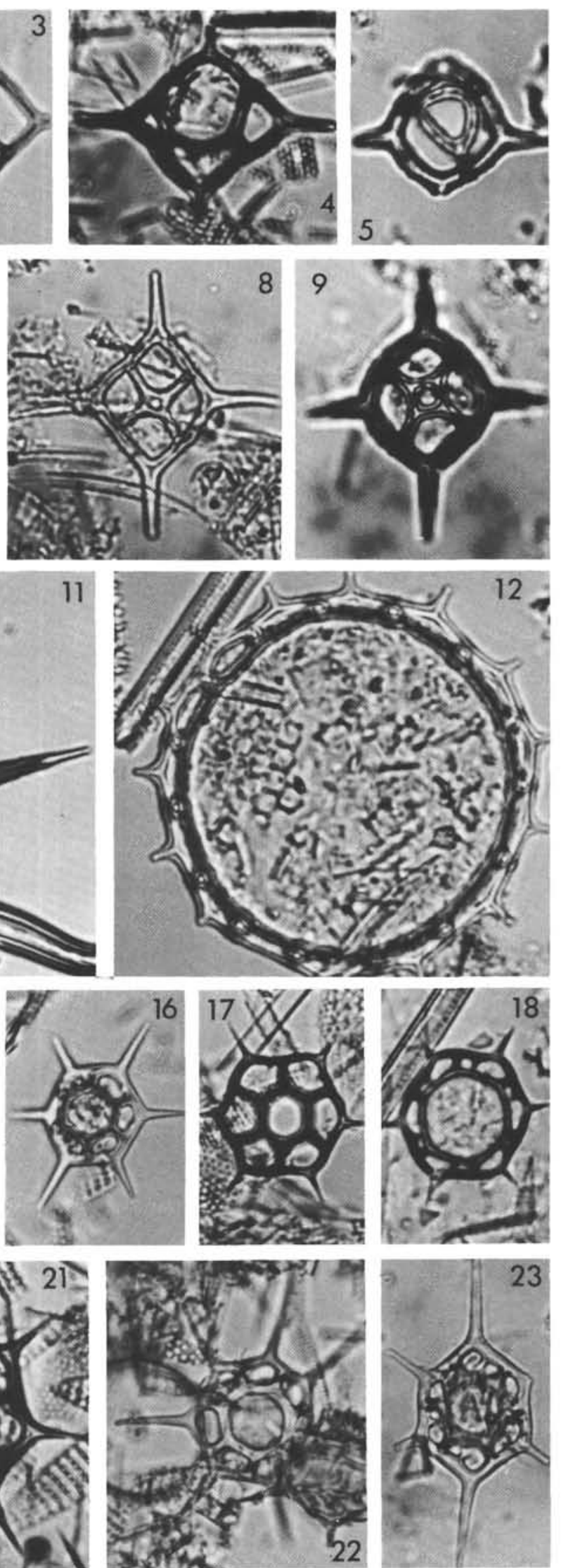
PLATE 8

Silicoflagellates

(Magnification $\sim \times 600$ )

Figures 1, 2 Corbisema inermis disymmetrica Dumitrica.

1. Sample $277-11-4,110 \mathrm{~cm}$.

2. Sample $277-13-4,110 \mathrm{~cm}$.

Figures 3, 4 Dictyocha? sp. 5. Sample 281-16, CC; high and low focus.

Figure 5 Mesocena sp. 1. Sample 283-5-2, $117 \mathrm{~cm}$.

Figure 6 Dictyocha? sp. 6. Sample 277-13-4, $110 \mathrm{~cm}$.

Figures 7, 8 Mesocena sp. 2. Sample 283-5-2, $117 \mathrm{~cm}$; high and low focus.

Figures 9, 10, Hannaites quadria Mandra

12-14 9, 12. Sample 283-5-2, $117 \mathrm{~cm}$.

10. Sample 283-3-1.

13. Sample 281-14, CC.

14. Sample 283-6, CC.

Figure 11 Distephanus sp. 1. Sample 277-22-2, 110 $\mathrm{cm}$. 
PLATE 8
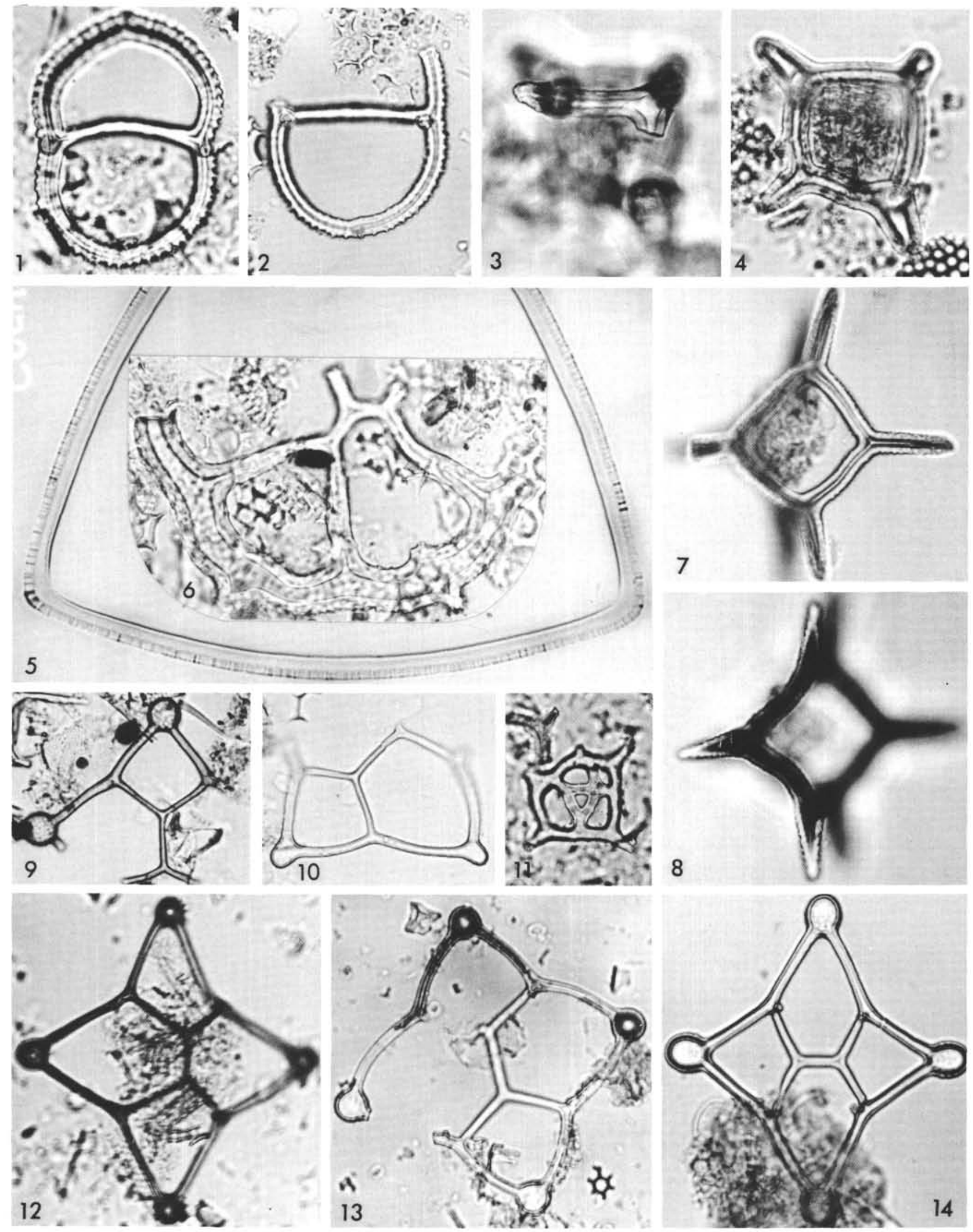
PLATE 9

Late Cretaceous Silicoflagellates

(Magnification $\sim \times 530$ )

Figures 1-7 Lyramula minor (Deflandre).

1, 6. Sample 275-1-3, $50 \mathrm{~cm}$.

2. Sample 275-1, CC.

$3,4,5,7$. Sample $275-1-1,130 \mathrm{~cm}$.

Figures 8-17 Lyramula deflandrei $\mathrm{n} . \mathrm{sp}$.

$8,15,16$. Sample $275-1-1,130 \mathrm{~cm}$.

9. Sample $275-1-1,130 \mathrm{~cm}$, Holotype.

10, 17. Sample $275-2-3,50 \mathrm{~cm}$.

11, 13. Sample $275-2-2,50 \mathrm{~cm}$.

12. Sample $275-2-4,50 \mathrm{~cm}$.

14. Sample 275-2, CC.

Figures 18-21, Lyramula furcula Hanna.

26,27

$18,19,20$. Sample $275-1-1,130 \mathrm{~cm}$.

21. Sample $275-1, \mathrm{CC}$.

26. Sample $275-2-3,50 \mathrm{~cm}$.

27. Sample $275-1-4,50 \mathrm{~cm}$.

Figures 22, 23, Dictyocha quadralta Hanna. Sample 275-2-

$28 \quad 3,50 \mathrm{~cm}$; Normal forms.

Figures 24, 25 Lyramula simplex Hanna.

24. Sample $275-2-3,50 \mathrm{~cm}$.

25. Sample 275-1-1, $130 \mathrm{~cm}$. 


\section{PLATE 9}
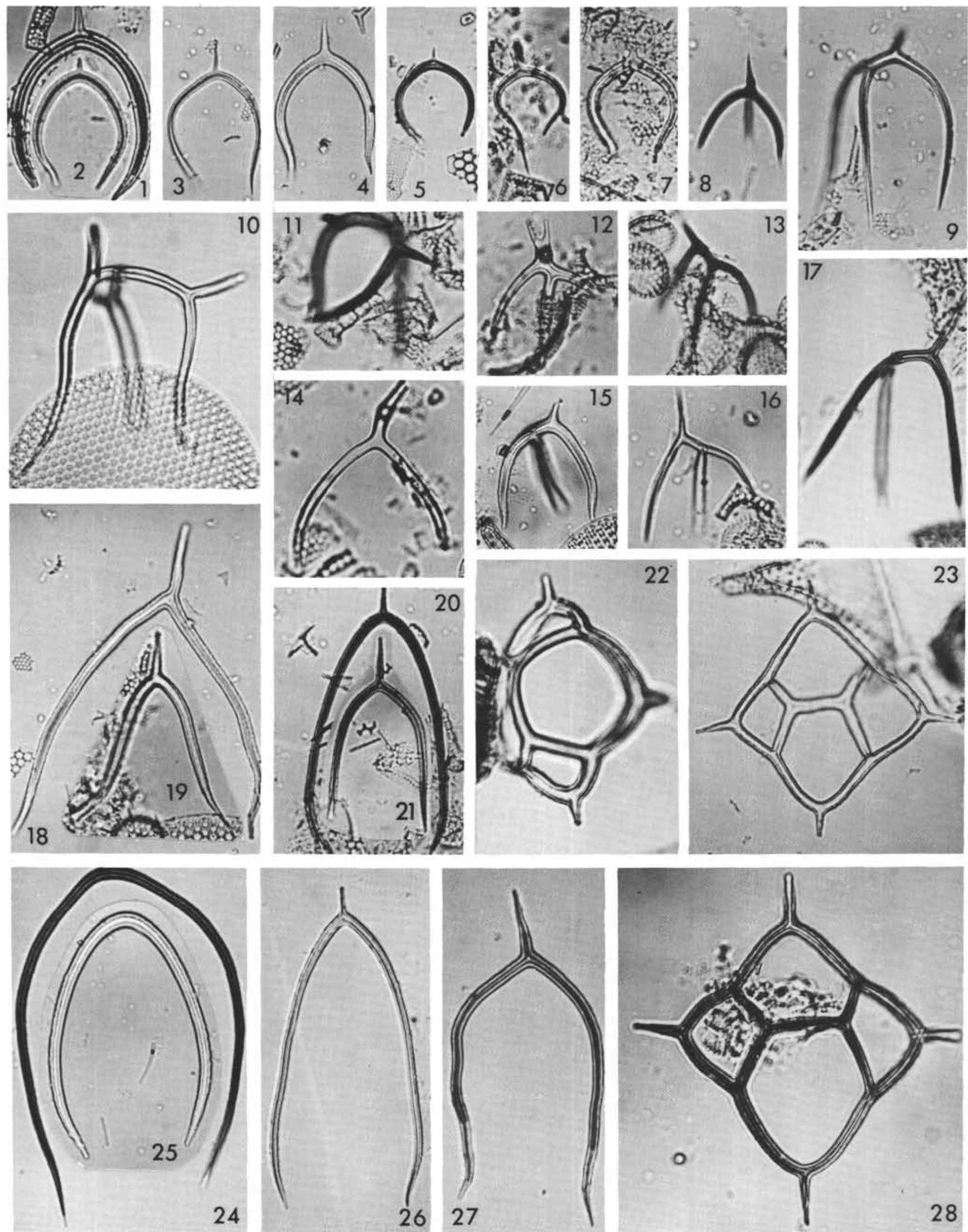
PLATE 10

Silicoflagellates

(Magnification $\sim \times 510$ )

Figure 1 Mesocena diodon Ehrenberg. Sample 278-9$1,110 \mathrm{~cm}$.

Figures 2, 3, Septamesocena apiculata (Schulz).

$5-8,10 \quad 2$. Sample 278-22-3, $110 \mathrm{~cm}$.

3. Sample $278-29$, CC.

5. Sample 278-27, CC.

6. Sample 278-20-6, $130 \mathrm{~cm}$.

7. Sample 281-16, CC.

8. Sample $277-9-4,110 \mathrm{~cm}$.

10. Sample $280 \mathrm{~A}-1-2,120 \mathrm{~cm}$.

Figures 4, 9 Mesocena pappii Bachmann.

4. Sample 278-29, CC.

9. Sample $278-20-6,130 \mathrm{~cm}$.

Figure 11 Septamesocena sp. Sample 280A-3, CC.

Figures 12, 13, Mesocena oamaruensis Schulz. 20 12. Sample $277-23-2,110 \mathrm{~cm}$.

13. Sample $280 \mathrm{~A}-5, \mathrm{CC}$.

20. Sample $277-21-2,110 \mathrm{~cm}$.

Figures 14, 19, Mesocena elliptica (Ehrenberg).

21-24 14, 19, 23, 24. Sample 278-20-6, $130 \mathrm{~cm}$.

21. Sample $280 \mathrm{~A}-1, \mathrm{CC}$.

22. Sample $278-9-1,110 \mathrm{~cm}$.

Figures 15, 16 Mesocena occidentalis Hanna.

15. Sample 280A-6, CC.

16. Sample $283-5-2,117 \mathrm{~cm}$.

Figures 17, 18 Septamesocena cf. S. quadrangula (Schulz).

17. Sample $277-21-2,110 \mathrm{~cm}$.

18. Sample 278-28, CC. 
PLATE 10
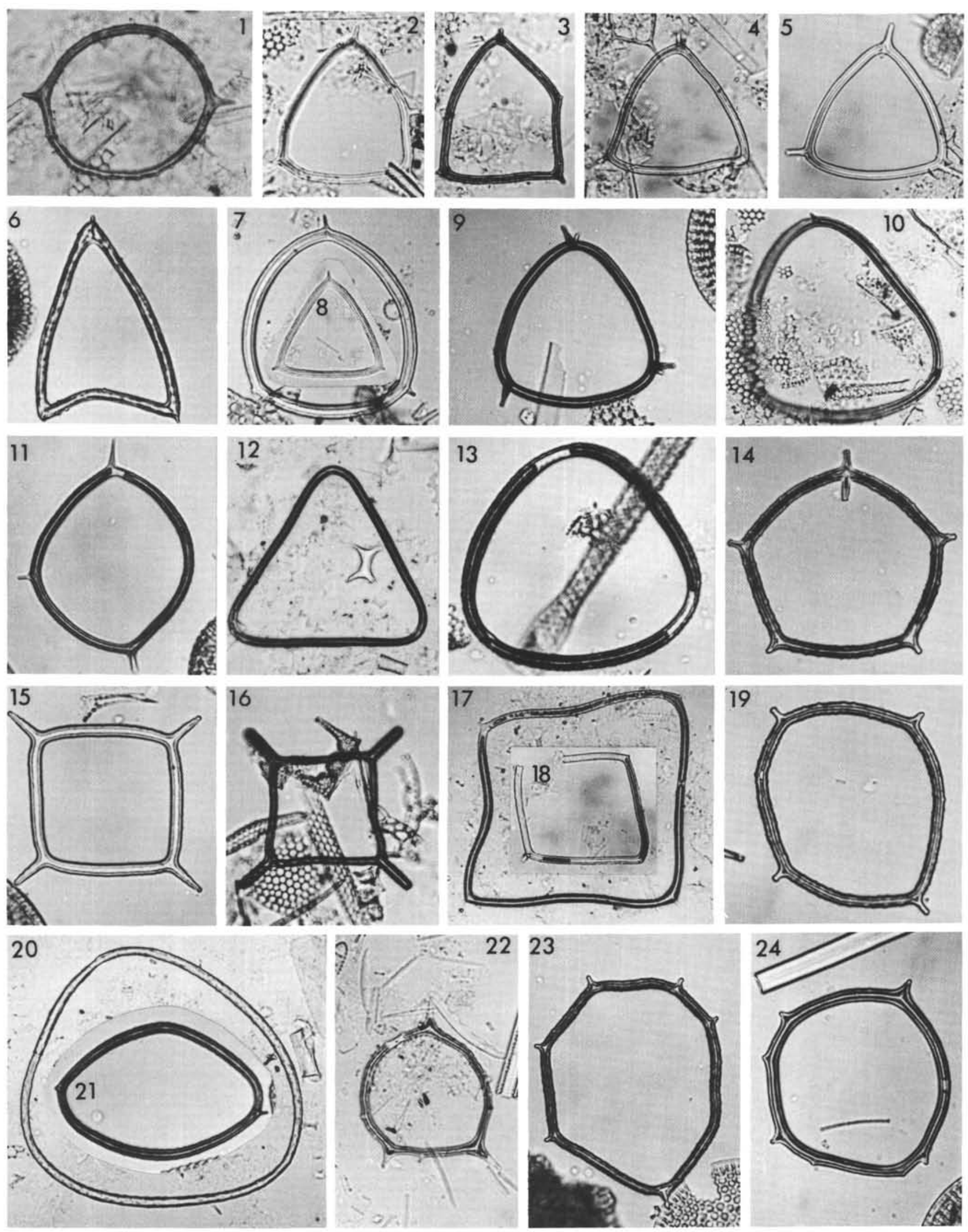

 
PLATE 11

Silicoflagellates

(Magnification $\sim \times 800$ )

Figures 1, 5-8 Paradictyocha dumitricae n.sp.

1, 6, 7. Sample 278-9-1, $110 \mathrm{~cm}$.

5, 8. Sample 278-8, CC.

Figures 2, 3, 4 Distephanus octogonus (Ehrenberg).

2, 3. Sample 278-3, CC.

4. Sample 278-6, CC.

Figures 9, 10, Paradictyocha $\mathrm{cf}$. P. apiculata (Lemmer13 mann). Sample 278-9-1, $110 \mathrm{~cm}$.

Figure 11 Distephanus polyactis (Ehrenberg). Sample 278-11-1, $110 \mathrm{~cm}$.

Figures 14, 15 Paradictyocha apiculata (Lemmermann). Sample 278-14, CC.

Figure 12 Paradictyocha circulus (Ehrenberg). Sample $278-9-1,110 \mathrm{~cm}$. 
PLATE 11
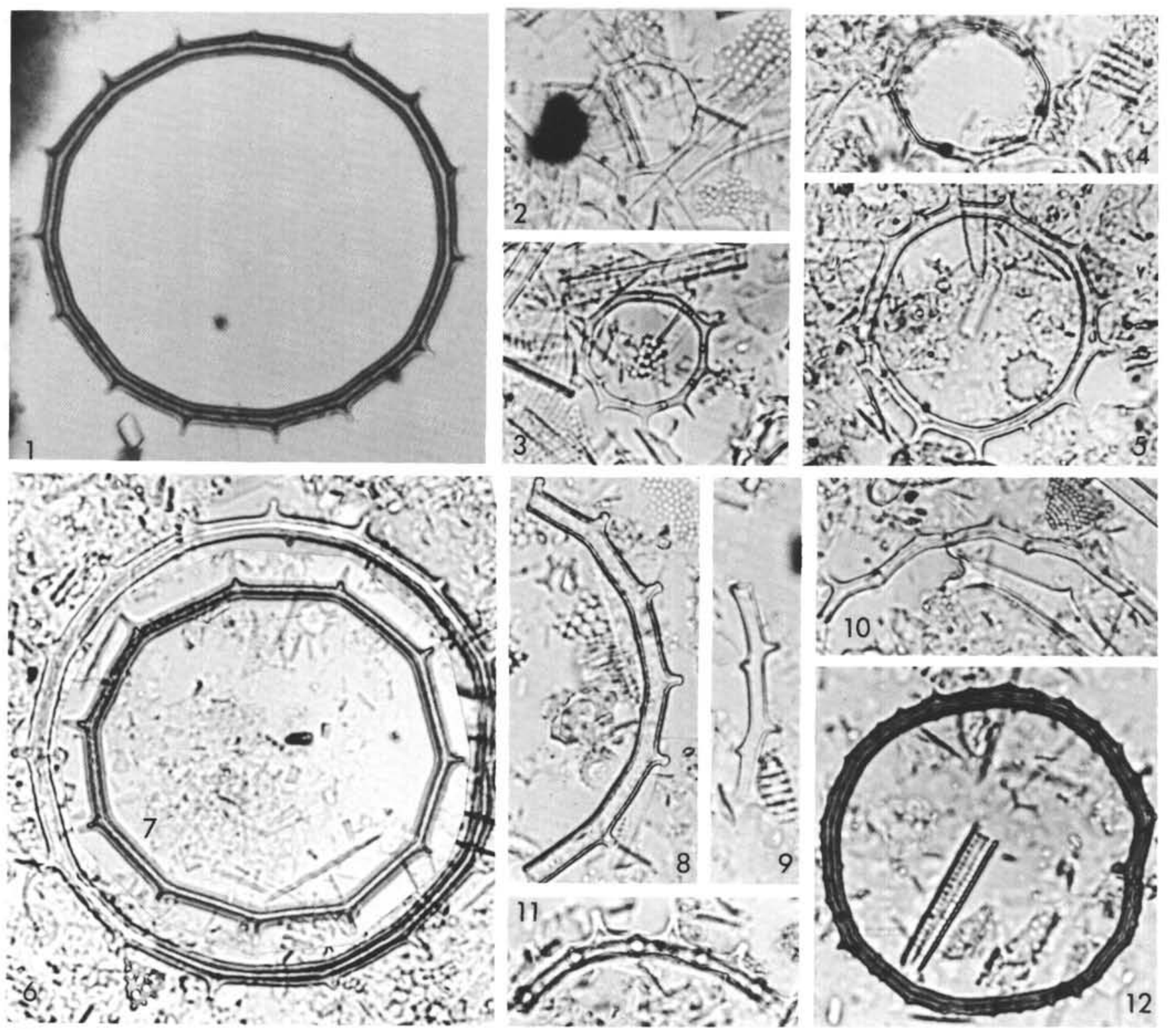

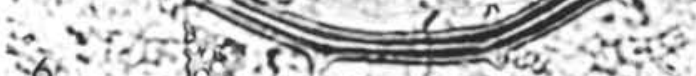

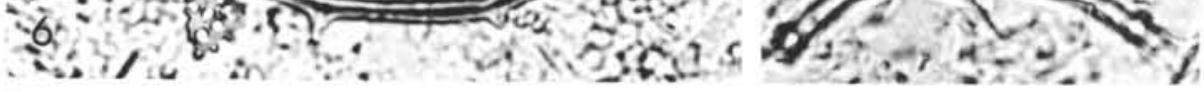
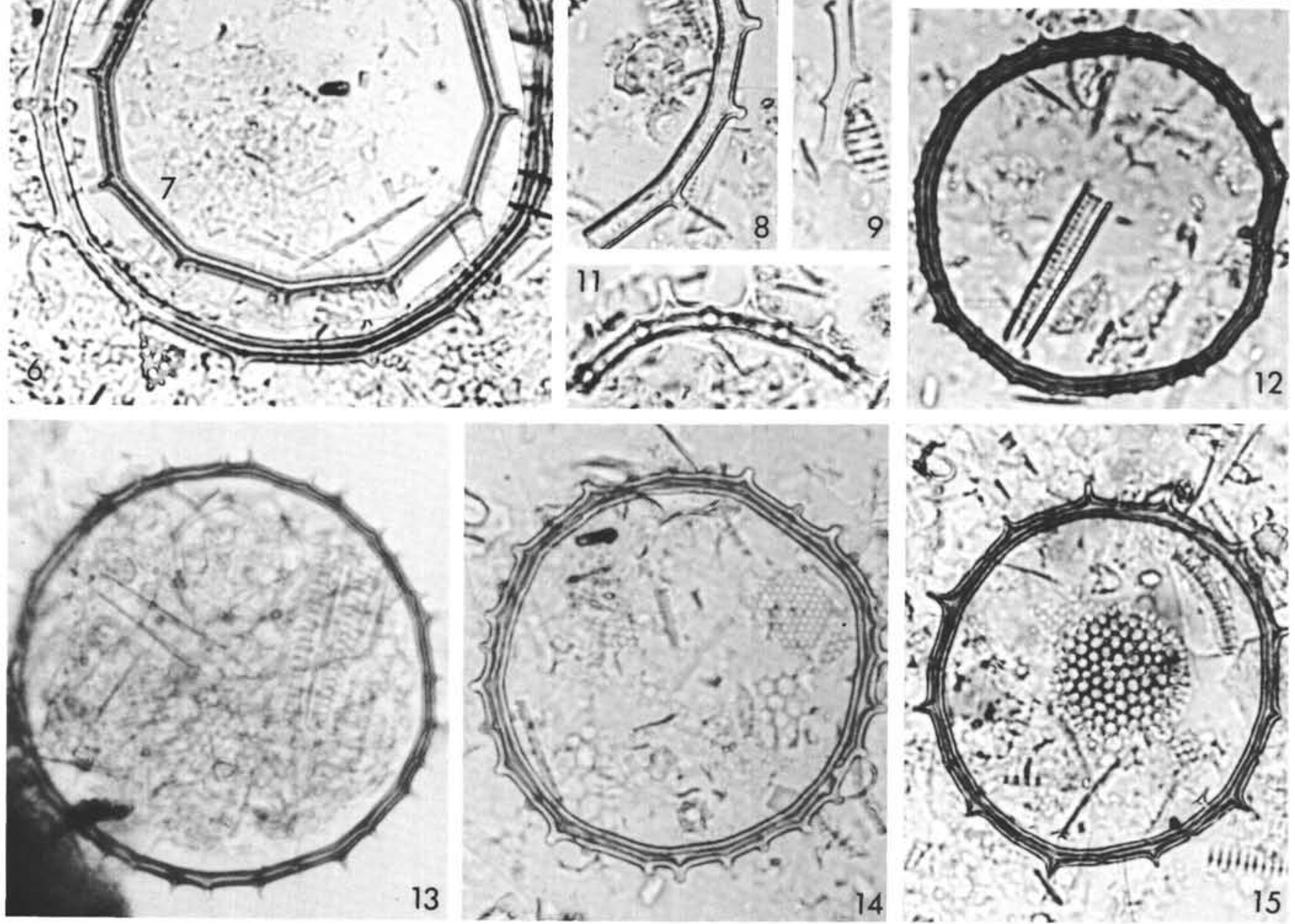


\section{PLATE 12}

Silicoflagellates

(Magnification $\sim \times 800$ )

Figures 1-4 Naviculopsis trispinosa (Schulz).

1, 2. Sample 280A-5, CC.

3. Sample $280 \mathrm{~A}-3-3,110 \mathrm{~cm}$.

4. Sample 278-30, CC.

Figures 5, $6 \quad$ Naviculopsis robusta Deflandre.

5. Sample 278-27, CC.

6. Sample $278-28, \mathrm{CC}$.

Figures 7,8 Naviculopsis lata (Deflandre).

7. Sample $278-22-3,110 \mathrm{~cm}$.

8. Sample $278-23-3,110 \mathrm{~cm}$.

Figures 9-14 Naviculopsis cf. $N$. lata (Deflandre). 9, 14. Sample $277-8-4,110 \mathrm{~cm}$.

10. Sample $277-9-4,110 \mathrm{~cm}$.

11, 13. Sample $277-17-4,110 \mathrm{~cm}$.

12. Sample 283-5-2, $117 \mathrm{~cm}$.

Figure $15 \quad$ Naviculopsis foliacea Deflandre. Sample $277-11-4,110 \mathrm{~cm}$.

Figures 16, 17, Naviculopsis constricta (Schulz).

23

16. Sample $277-18-2,110 \mathrm{~cm}$.

17. Sample $283-5-2,117 \mathrm{~cm}$.

23. Sample $277-21-2,110 \mathrm{~cm}$.

Figures 18-22 Naviculopsis biapiculata s.1. (Lemmermann).

18, 19. Sample 278-29, CC.

20. Sample $278-31-2,110 \mathrm{~cm}$.

21. Sample 277-23-2, $110 \mathrm{~cm}$.

22. Sample $277-23-2,110 \mathrm{~cm}$; abnormal form. 
PLATE 12
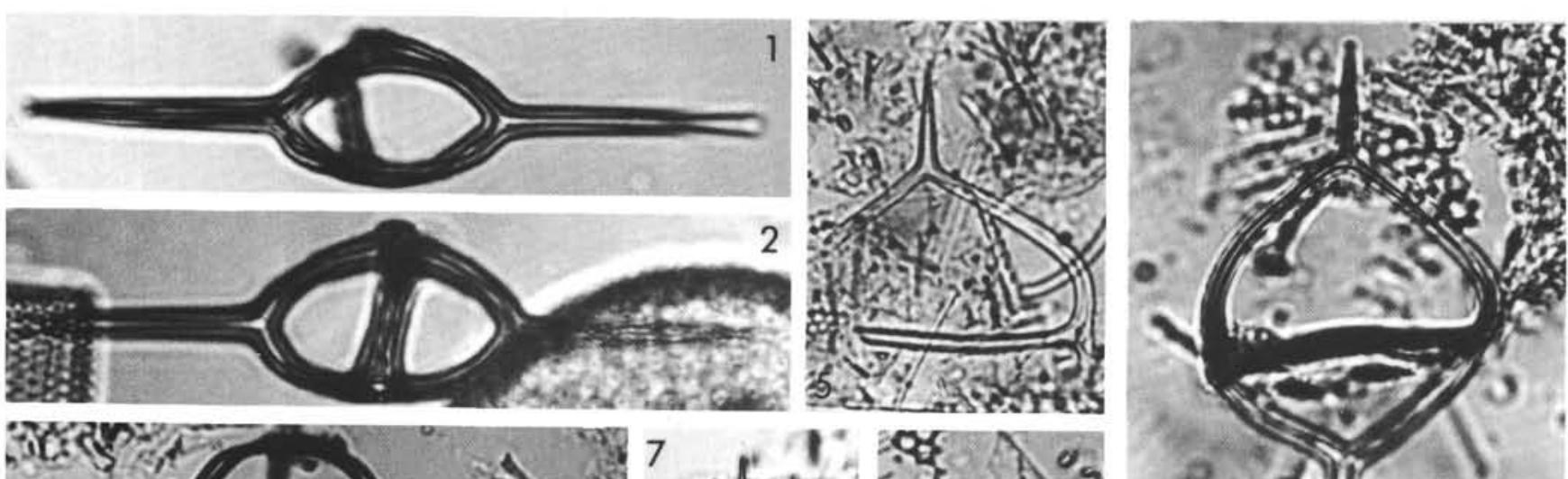

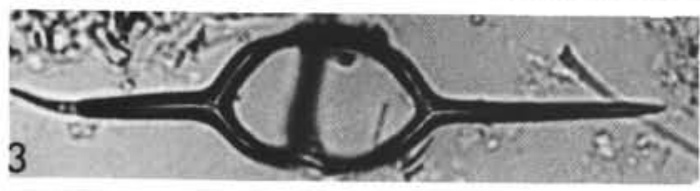

\section{s.}

$\sqrt{7}$

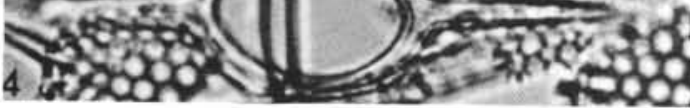
2. V. 2...…
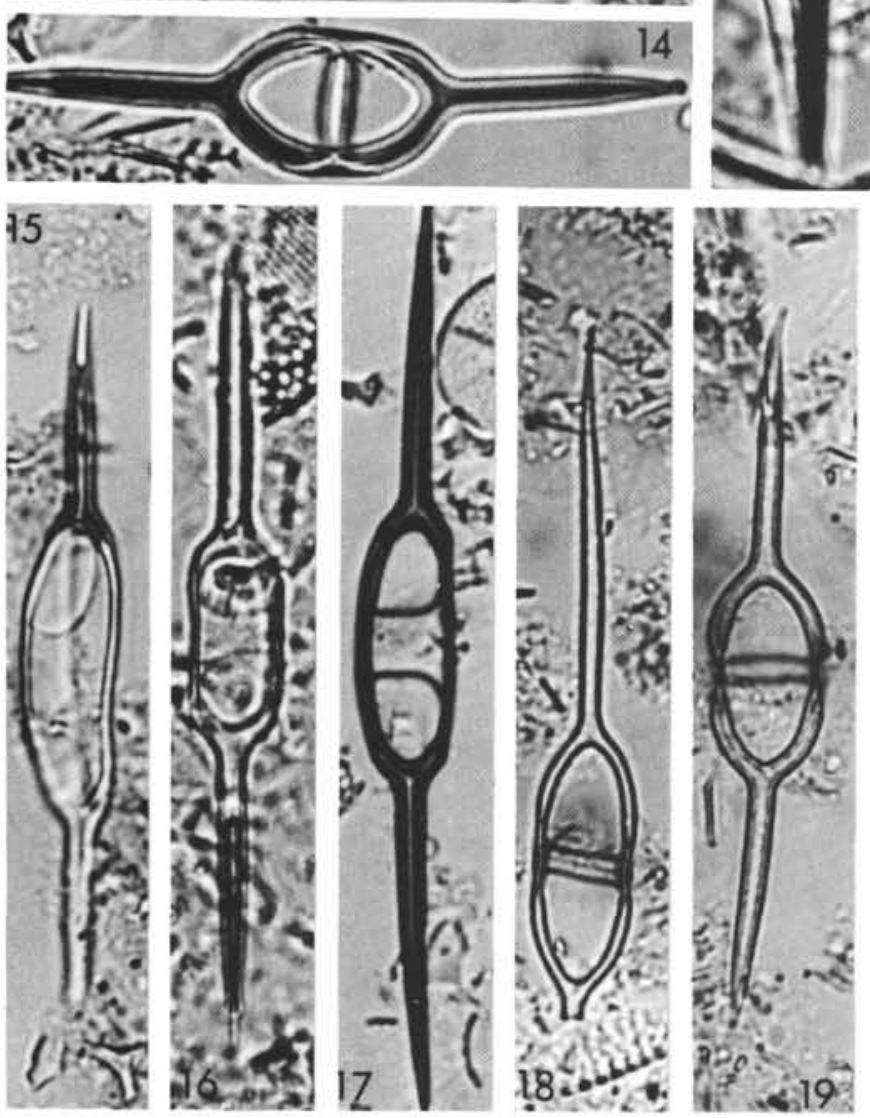

\section{की} at 2
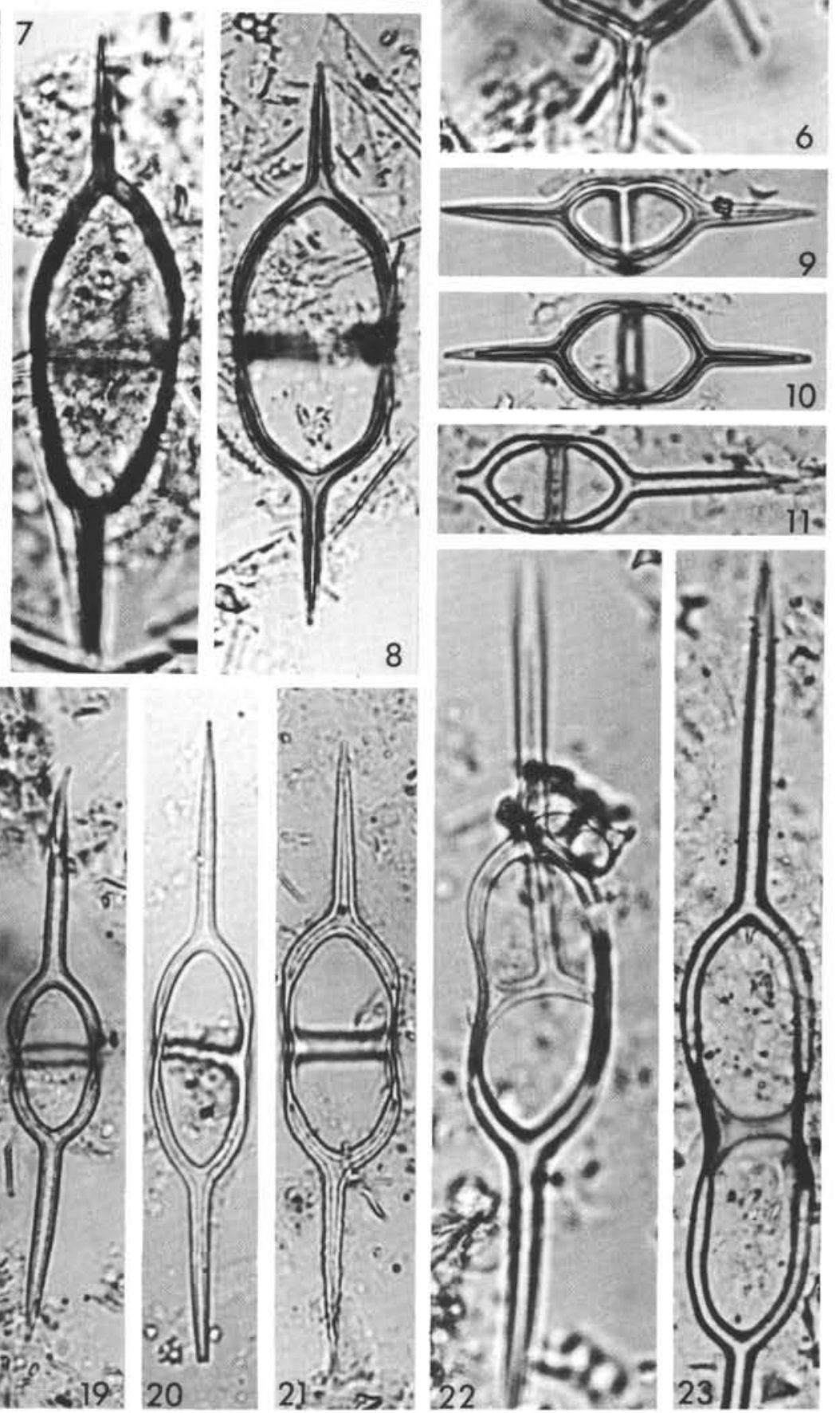
PLATE 13

Silicoflagellates

( Magnification $\sim \times 800$ )

Figures 1-10 Naviculopsis trispinosa (Schulz).

1. Sample 280A-5, CC.

2. Sample $283-5-2,117 \mathrm{~cm}$.

3. Sample $277-9-4,110 \mathrm{~cm}$.

4-8, 10. Sample 280A-3, CC.

9. Sample $277-5-4,110 \mathrm{~cm}$.

Figures 11, 12 ?Mesocena sp.3.

11. Sample 278-29, CC.

12. Sample $278-22-3,110 \mathrm{~cm}$. 
PLATE 13
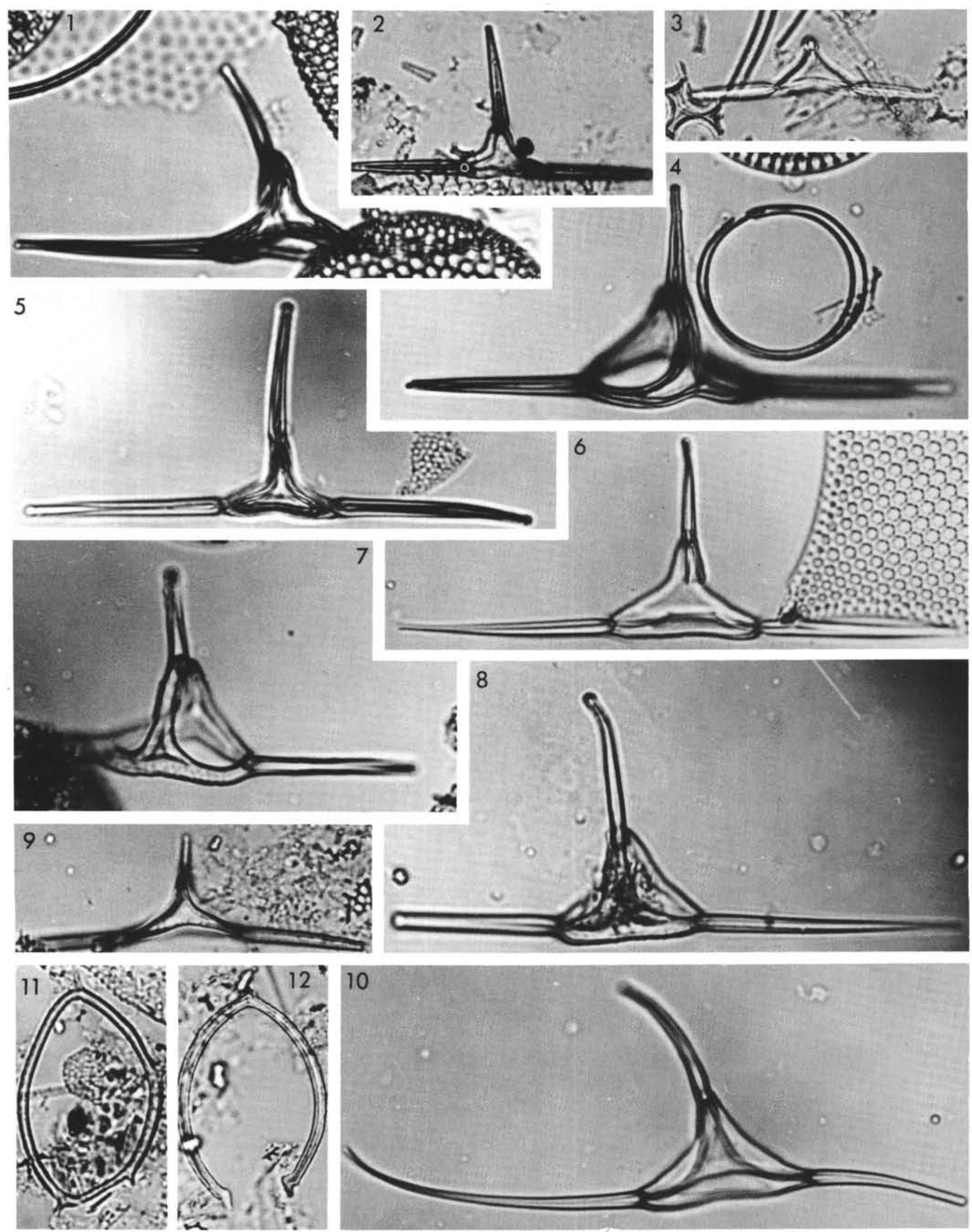
PLATE 14

Late Cretaceous Silicoflagellates

(Magnification $\sim \times 880$ )

Figures 1, 4, Vallacerta cf. V. tumidula Glezer.

9, $10 \quad 1,4,9$. Sample 275-2-4, $50 \mathrm{~cm}$.

10. Sample $275-2-3,50 \mathrm{~cm}$.

Figures 2, 5, Vallacerta hortonii Hanna.

$7,8 \quad 2,7,8$. Sample $275-1-1,130 \mathrm{~cm}$.

5. Sample $275-2-2,50 \mathrm{~cm}$.

Figures 3, $6 \quad$ Vallacerta sidera (Schulz).

3. Sample $275-1-3,50 \mathrm{~cm}$.

6. Sample $275-1-1,130 \mathrm{~cm}$.

Figure $11 \quad$ Corbisema geometrica (?) Hanna. Sample 275-1-3, $50 \mathrm{~cm}$; central part only. 
PLATE 14
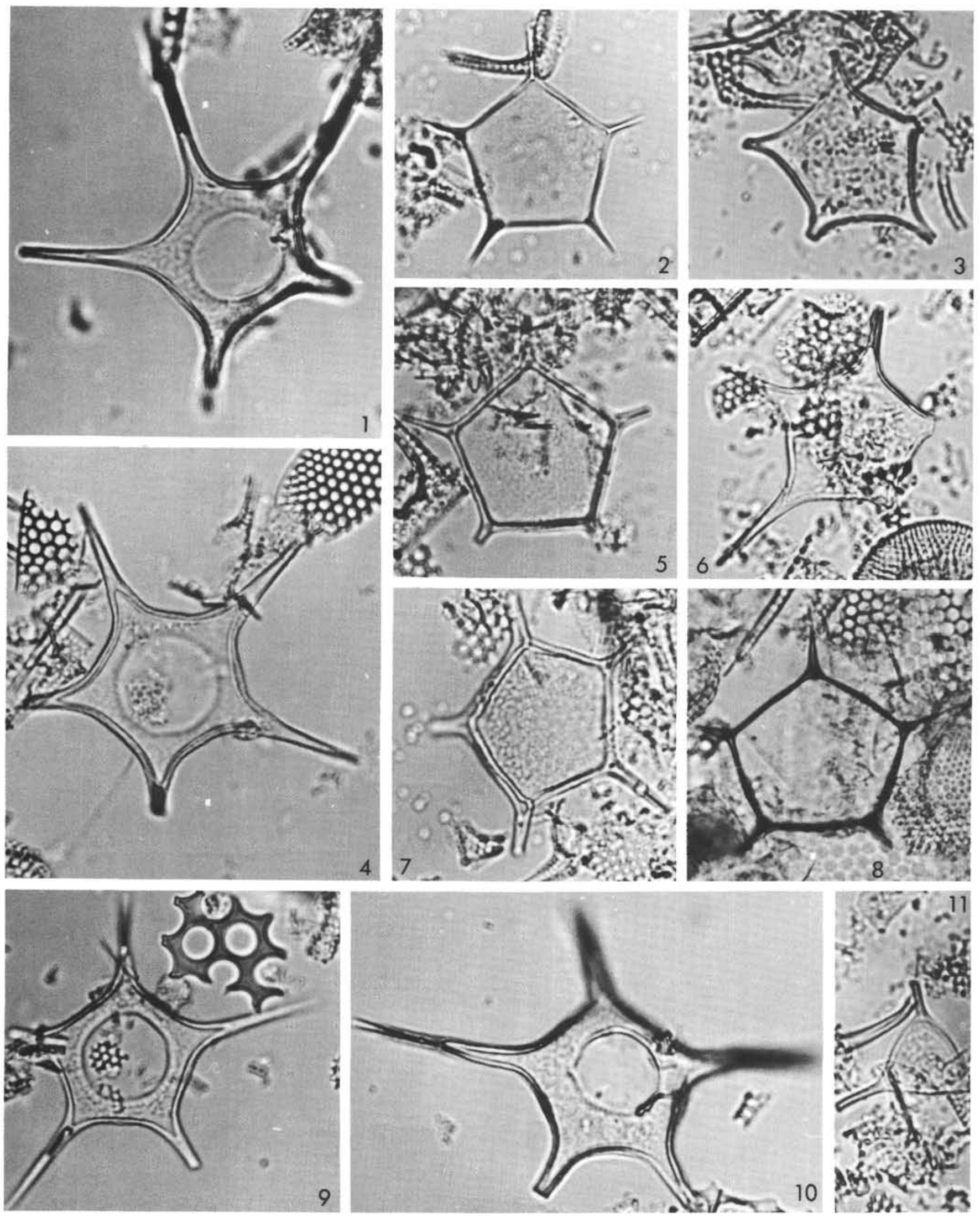
PLATE 15

Silicoflagellates from Sample 280A-5-1, $110 \mathrm{~cm}$, early Oligocene

Figures 1, 2 Corbisema apiculata (Lemmermann)

1. $\times 1680 ; 0^{\circ}$.

2. $\times 1680 ; 25^{\circ}$.

Figure 3 Corbisema recta (Schulz). $\times 2400 ; 0^{\circ}$.

Figure 4 Dictyocha pentagona (Schulz). $\times 2400 ; 0^{\circ}$.

Figures 5-7 Dictyocha medusa Haeckel. $\times 2400 ; 0^{\circ}$.

Figure $8 \quad$ Distephanus crux (Ehrenberg). $\times 2500 ; 25^{\circ}$.

Figure $9 \quad$ Naviculopsis cf. $N$. lata $($ Deflandre). $\times 1320$; $25^{\circ}$. 
PLATE 15
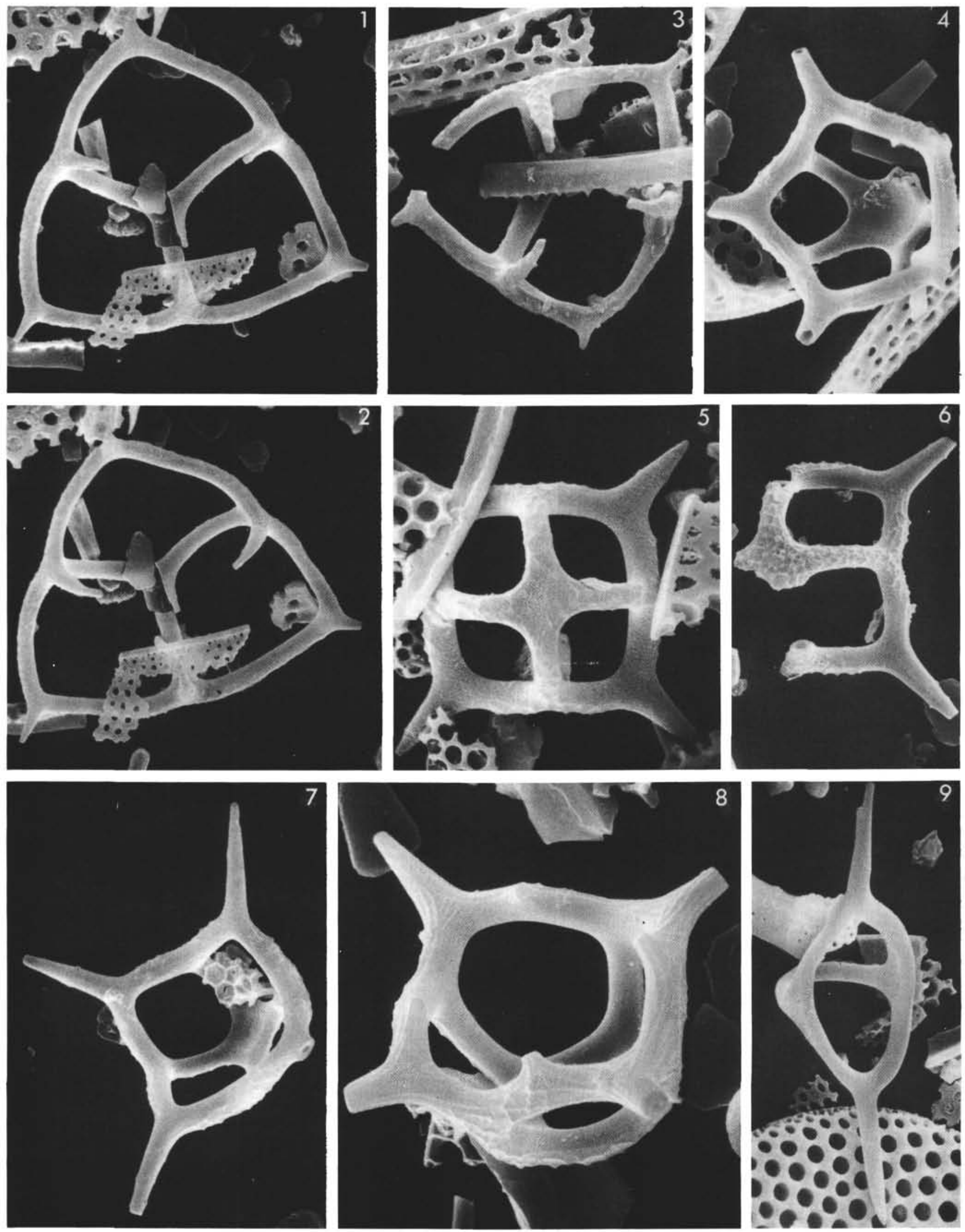